\title{
Arsenian Pyrite and Cinnabar from Active Submarine Nearshore Vents, Paleochori Bay, Milos Island, Greece
}

\author{
Panagiotis Voudouris ${ }^{1, *(\mathbb{D})}$, Marianna Kati ${ }^{1}$, Andreas Magganas ${ }^{1}{ }^{(\mathbb{C}}$, Manuel Keith ${ }^{2}$, Eugenia Valsami-Jones ${ }^{3} \mathbb{D}$, \\ Karsten Haase ${ }^{2}$, Reiner Klemd ${ }^{2}$ and Mark Nestmeyer ${ }^{2}$
}

1 Faculty of Geology and Geoenvironment, National and Kapodistrian University of Athens, 15784 Athens, Greece; kati@geol.uoa.gr (M.K.); amagganas@geol.uoa.gr (A.M.)

2 GeoZentrum Nordbayern, University of Erlangen-Nuremberg, 91054 Erlangen, Germany; manuel.keith@fau.de (M.K.); karsten.haase@fau.de (K.H.); reiner.klemd@fau.de (R.K.); marknestmeyer@outlook.de (M.N.)

3 School of Geography, Earth and Environmental Sciences, University of Birmingham, Edgbaston, Birmingham B15 2TT, UK; E.ValsamiJones@bham.ac.uk

* Correspondence: voudouris@geol.uoa.gr; Tel.: +30-210-727-4129

Citation: Voudouris, P.; Kati, M.;

Magganas, A.; Keith, M.;

Valsami-Jones, E.; Haase, K.; Klemd, R.; Nestmeyer, M. Arsenian Pyrite and Cinnabar from Active Submarine Nearshore Vents, Paleochori Bay, Milos Island, Greece. Minerals 2021, 11, 14. https://dx.doi.org/10.3390 $/ \min 11010014$

Received: 4 December 2020 Accepted: 21 December 2020 Published: 25 December 2020

Publisher's Note: MDPI stays neutral with regard to jurisdictional claims in published maps and institutional affiliations.

Copyright: (c) 2020 by the authors. Licensee MDPI, Basel, Switzerland. This article is an open access article distributed under the terms and conditions of the Creative Commons Attribution (CC BY) license (https: / / creativecommons.org/ licenses/by/4.0/).
Abstract: Active, shallow-water (2-10 m below sea level) and low temperature (up to $115{ }^{\circ} \mathrm{C}$ ) hydrothermal venting at Paleochori Bay, nearshore Milos Island, Greece, discharges $\mathrm{CO}_{2}$ and $\mathrm{H}_{2} \mathrm{~S}$ rich vapors (e.g., low-Cl fluid) and high-salinity liquids, which leads to a diverse assemblage of sulfide and alteration phases in an area of approximately $1 \mathrm{~km}^{2}$. Volcaniclastic detritus recovered from the seafloor is cemented by hydrothermal pyrite and marcasite, while semi-massive to massive pyrite-marcasite constitute mounds and chimney-like edifices. Paragenetic relationships indicate deposition of two distinct mineralogical assemblages related to the venting of high- $\mathrm{Cl}$ and low-Cl fluids, respectively: (1) colloform As- and Hg-bearing pyrite (Py I), associated with marcasite, calcite, and apatite, as well as (2) porous and/or massive As-rich pyrite (Py II), associated with barite, alunite/jarosite, and late-stage hydrous ferric oxides. Mercury, in the form of cinnabar, occurs within the As-rich pyrite (Py I) layers, usually forming distinct cinnabar-enriched micro-layers. Arsenic in colloform pyrite I shows a negative correlation with $\mathrm{S}$ indicating that $\mathrm{As}^{1-}$ dominates in the pyrite structure suggesting formation from a relatively reducing As-rich fluid at conditions similar to low-sulfidation epithermal systems. On the contrary, $\mathrm{As}^{3+}$ dominates in the structure of porous to massive pyrite II suggesting deposition from a sulfate-dominated fluid with lower $\mathrm{pH}$ and higher $\mathrm{fO}_{2}$. Bulk sulfide data of pyrite-bearing hydrothermal precipitates also show elevated As (up to $2587 \mathrm{ppm}$ ) together with various epithermal-type elements, such as $\mathrm{Sb}$ (up to $274 \mathrm{ppm}$ ), $\mathrm{Tl}$ (up to $513 \mathrm{ppm}$ ), and $\mathrm{Hg}$ (up to $34 \mathrm{ppm}$ ) suggesting an epithermal nature for the hydrothermal activity at Paleochori Bay. Textural relationships indicate a contemporaneous deposition of As and $\mathrm{Hg}$, which is suggested to be the result of venting from both high-salinity, liquid-dominated, as well as $\mathrm{CO}_{2}$ - and $\mathrm{H}_{2} \mathrm{~S}$-rich vapor-dominated fluids that formed during fluid boiling. The $\mathrm{CO}_{2}$ - and $\mathrm{H}_{2} \mathrm{~S}$-rich vapor that physically separated during fluid boiling from the high-salinity liquid led to calcite formation upon condensation in seawater together with the precipitation of As- and Hg-bearing pyrite I. This also led to the formation of sulfuric acid, thereby causing leaching and dissolution of primary iron-rich minerals in the volcaniclastic sediments, finally resulting in pyrite II precipitation in association with alunite/jarosite. The Paleochori vents contain the first documented occurrence of cinnabar on the seafloor in the Mediterranean area and provide an important link between offshore hydrothermal activity and the onshore mercury and arsenic mineralizing system on Milos Island. The results of this study therefore demonstrate that metal and metalloid precipitation in shallow-water continental arc environments is controlled by epithermal processes known from their subaerial analogues.

Keywords: boiling; shallow-water hydrothermal activity; sulfide mound; low-sulfidation epithermal; steam-heated alunite; cinnabar 


\section{Introduction}

During the last decades, research on seafloor hydrothermal systems mainly focused on high-temperature vent fields (up to $\sim 400{ }^{\circ} \mathrm{C}$ ) at mid-ocean ridges and in subduction zone-related extensional basins [1-11]. Hydrothermal venting in back-arc settings like the Lau Basin [12,13], the North Fiji Basin [14], the New Hebrides back-arc [15], and the Mariana Trough [16], as well as in rifted arcs such as the Manus basin [17] and the Okinawa trough [18] typically occurs at water depths of about 1500 to $2500 \mathrm{~m}$ [19]. In contrast, submarine hydrothermal vents in arc settings are more often found at water depths between 200 and $1500 \mathrm{~m}$ [19]. Examples include the Tonga-Kermadec intra-oceanic arc [9,20-23] and the Kolumbo volcano in the Hellenic continental volcanic arc [24]. Submarine hydrothermal vents depositing sulfides or sulfates at shallower water depths $(<200 \mathrm{~m})$ are much less common and only little is known about their physicochemical formation conditions [25-28]. Examples of hydrothermal mineralization at shallow depths include Lihir and Ambitle Island, Papua New Guinea [29-31]; Punta Mita and Bahia Concepcion, Mexico [32-35]; Punta Banda, Baja California [36,37]; Bay of Plenty, New Zealand [38]; Baia di Levante at Vulcano, Aeolian arc, Italy [39]; and Paleochori Bay nearshore Milos, Hellenic continental arc, Greece $[27,28,40,41]$ (Figure 1).

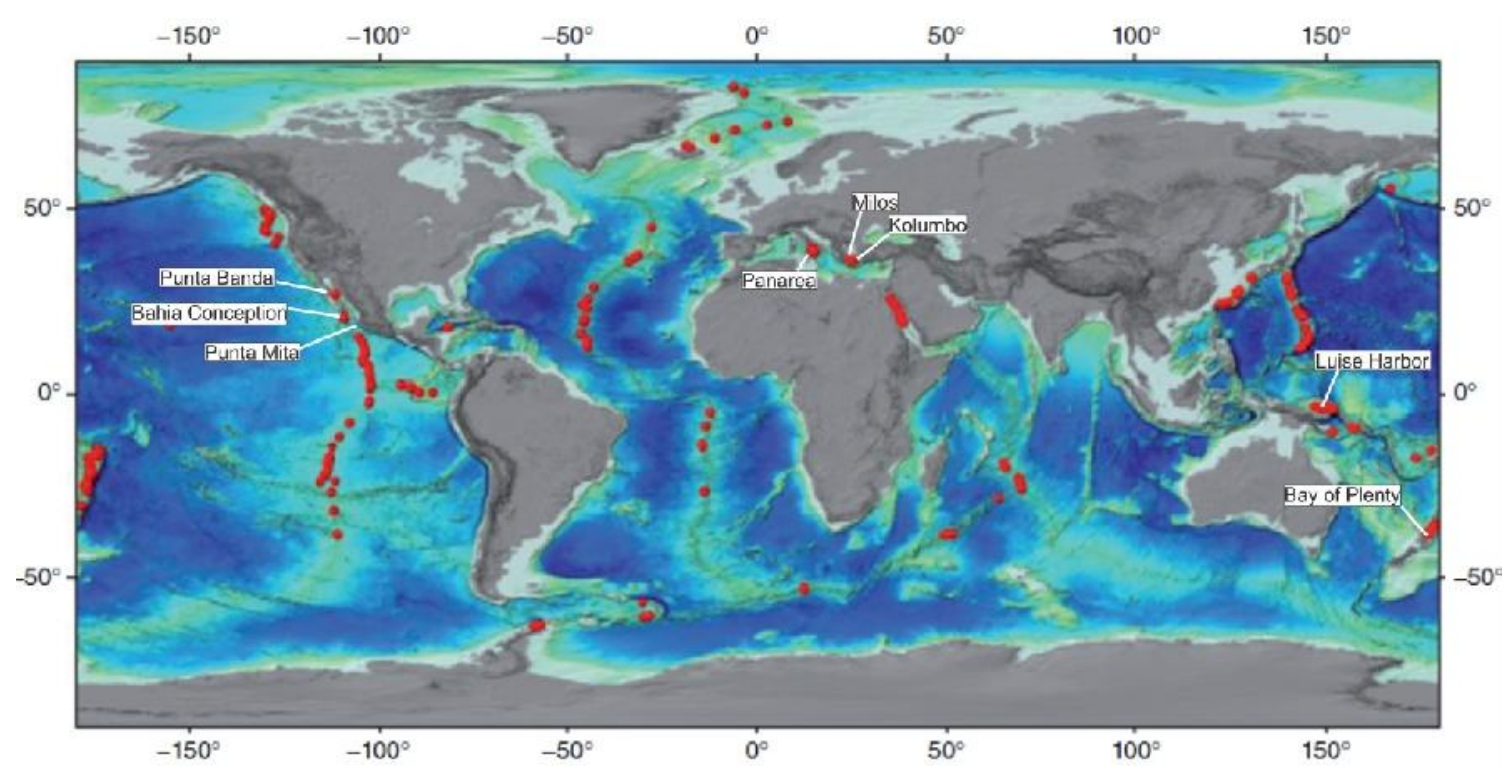

Figure 1. Map showing the location of hydrothermal deposits discovered on the seafloor including locations of some very shallow and shallow-water hydrothermal vents discussed in this study (adapted from Jamieson et al. [42]).

Compared to their deeper arc-related settings (200 to $1500 \mathrm{~m}$ below sea level, i.e. mbsl), the shallow water depth $(<200 \mathrm{mbsl})$ of these systems implies that they typically occur nearshore to a volcanic center characterized by a thick volcaniclastic cover, which has a significant imprint on the fluid composition and the conditions of formation of the hydrothermal precipitates [30,32,41,43-50]. These shallow aqueous hydrothermal systems are characterized by fluid boiling caused by the increasing density contrast of vapor and liquid with decreasing temperature and pressure conditions [51]. This leads to the discharge of both gas bubbles (vapor-dominated fluids) and liquids at "gasohydrothermal" shallow marine vent sites $[28,40,52,53]$.

Milos Island, Greece is known for its mineral wealth, exploited from ancient to recent times. Industrial minerals, as well as base and precious metal epithermal deposits, are related to long-standing hydrothermal activity since the Pliocene [54-61]. The active nearshore expressions (e.g., Paleochori Bay) of the Milos epithermal/geothermal system have attracted research, mainly with respect to metal and metalloid enrichment and fractionation in the hydrothermal fluids (e.g., [28,44-46]). However, only little attention has been given to the subaqueous sulfide precipitation, despite its profound importance for 
providing a better understanding of the mineralization processes in shallow submarine and onshore environments $[40,41,43,47-50,53,62-66]$. The link between the nearshore and onshore mineralization at Milos is still poorly investigated [57,60], and thus improving our understanding of the seafloor hydrothermal processes at Paleochori Bay will also help to better constrain the formation conditions of the onshore epithermal mineralization of Milos Island.

This study expands on previous work of Kati et al. [67,68], and presents new data from Paleochori Bay reporting on the occurrence of $\mathrm{Hg}$ and $\mathrm{Tl}$ enrichments associated with As-rich pyrite mineralization in actively forming hydrothermal vents in a very shallow marine continental volcanic arc setting. Active cinnabar formation is a rare feature of submarine hydrothermal systems, and this study reports for the first time on the occurrence of actively formed cinnabar on the sea floor in the Aegean and the Mediterranean area. This study aims to present an integrated view of the atypical mineralization of Paleochori Bay focusing on the mineral constituents, bulk and mineral chemistry, mineralization sequence, and physicochemical formation conditions. This provides new insights into the hydrothermal metallogeny of Milos Island and demonstrates that metal and metalloid precipitation in shallow-water continental arc environments is controlled by epithermal processes known from their subaerial analogues.

\section{Materials and Methods}

Sulfide grab samples were recovered from ten sites in an area of about $450 \mathrm{~m} \times 250 \mathrm{~m}$ on the seafloor of Paleochori Bay (Table 1 and Figures 2 and 3). Sampling took place over four field seasons (1996-1999) by scuba diving. The collected material was taken from sulfide edifices (mounds and chimney-like structures) and metalliferous sediment in the immediate vicinity of areas of active discharge, where hydrothermal fluids were sampled and described in detail by Valsami-Jones et al. [41]. The samples are considered to be representative, adequately describing the situation at Paleochori Bay.

A total of 31 mineralized samples were examined by optical microscopy, X-ray diffraction (XRD), scanning electron microscopy (SEM), electron probe micro-analysis (EPMA), and cathodoluminescence. X-ray diffraction measurements $(n=26)$ were carried out in the Department of Geology and Geoenvironment at the National and Kapodistrian University of Athens, using a Siemens (Bruker) D5005 X-ray diffractometer at the following conditions: $\mathrm{CuKa}$ radiation $(40 \mathrm{kV}, 40 \mathrm{~mA}), 3-65^{\circ} 2 \theta$ range, $0.02^{\circ}$ step size, and $1 \mathrm{~s}$ step time. For the mineralogical identification, the DIFFRAC v. 2.41 and EVA v. 10.0 software package was used.

Selected samples $(n=19)$ were examined with a JEOL JSM 5600 scanning electron microscope equipped with back-scattered imaging capabilities in the Department of Mineralogy and Petrology at the National and Kapodistrian University of Athens. Metallic and non-metallic minerals were identified by electron probe micro-analysis (EPMA) in 16 samples using a Cameca-SX 100 wavelengthdispersive system at the Natural History Museum, London. An acceleration voltage of $20 \mathrm{kV}$, a beam current of $20 \mathrm{nA}$, and a focused beam were used as operating conditions. The following x-ray lines were used: $\mathrm{AlK} \alpha, \mathrm{AsL} \alpha, \operatorname{BaL} \alpha$, $\mathrm{CaK} \alpha, \mathrm{CoK} \alpha, \mathrm{CuK} \alpha, \operatorname{HgM} \alpha, \mathrm{KK} \alpha, \mathrm{FeK} \alpha, \operatorname{MgK} \alpha, \operatorname{MnL} \alpha, \mathrm{NaK} \alpha, \mathrm{NiK} \alpha, \mathrm{PK} \alpha, \mathrm{PbM} \alpha, \mathrm{SK} \alpha$, $\mathrm{SrL} \alpha$, and $\mathrm{ZnK} \alpha$. Corrections were applied using the PAP online program [69]. Pyrite (Fe, $\mathrm{S})$ and chalcopyrite $(\mathrm{Cu})$, galena $(\mathrm{Pb})$, sphalerite $(\mathrm{Zn})$, cinnabar $(\mathrm{Hg})$, skutterudite $(\mathrm{Co})$, millerite for $\mathrm{Ni}$, and synthetic GaAs (As) were used as reference materials for the analysis of pyrite. Average detection limits are as follows: S (331 ppm), Fe (383 ppm), Cu (771 ppm), Zn (547 ppm), As (879 ppm), Hg (965 ppm), Mn (95 ppm), Co (150 ppm), Ni (150 ppm), and $\mathrm{Zn}$ (547). For the analysis of barite and calcite, the following standards were used: orthoclase $(\mathrm{K})$, albite $(\mathrm{Na})$, andradite $(\mathrm{Ca}, \mathrm{Fe})$, apatite $(\mathrm{P}), \mathrm{Ba}$-glass $(\mathrm{Ba}), \mathrm{SrTiO}_{3}(\mathrm{Sr}), \mathrm{Pb}$-glass $(\mathrm{Pb}), \mathrm{Al}_{2} \mathrm{O}_{3}(\mathrm{Al})$, and $\mathrm{BaSO}_{4}(\mathrm{~S})$. Standard deviations of the major oxides were within 1-2\%. Oxides and elements were analyzed and their average $(1 \sigma)$ detection limits were: $\mathrm{MgO}$ (0.43 wt \%), $\mathrm{MnO}\left(0.054\right.$ wt \%), $\mathrm{FeO}$ (0.057 wt \%), $\mathrm{SrO}\left(0.082\right.$ wt \%), $\mathrm{BaO}\left(0.094\right.$ wt \%), $\mathrm{K}_{2} \mathrm{O}$ $\left(0.032\right.$ wt \%), $\mathrm{CaO}\left(0.038\right.$ wt \%), and $\mathrm{SO}_{3}(0.063 \mathrm{wt} \%)$. 
The chemical composition of alunite-jarosite was determined at the Department of Geology and Geoenvironment, National and Kapodistrian University of Athens (NKUA), by a JEOL JSM 5600 scanning electron microscope (SEM) (JEOL, Tokyo, Japan), equipped with the ISIS 300 OXFORD automated energy-dispersive X-ray instrument, with the following operating conditions: accelerating voltage, $20 \mathrm{kV}$; beam current, $0.5 \mathrm{nA}$; time of measurement (dead time), $50 \mathrm{~s}$; and beam diameter, 1-2 $\mu \mathrm{m}$. The following $X$-ray lines were used: $\mathrm{AlK} \alpha \mathrm{CaK} \alpha, \mathrm{KK} \alpha, \mathrm{FeK} \alpha, \mathrm{NaK} \alpha, \mathrm{PK} \alpha$, and $\mathrm{SK} \alpha$. Standards used were orthoclase $(\mathrm{K})$, $\mathrm{NaCl}(\mathrm{Na})$, andradite $(\mathrm{Ca}, \mathrm{Fe})$, apatite $(\mathrm{P}), \mathrm{Ba}$-glass $(\mathrm{Ba}), \mathrm{SrTiO}_{3}(\mathrm{Sr}), \mathrm{Al}_{2} \mathrm{O}_{3}(\mathrm{Al})$, and pyrite $(\mathrm{S})$.

Cathodoluminescence images were obtained at the Natural History Museum, London, using a CITL CL8200 Mk4 cold cathode system (350 $\mu \mathrm{A}$ and $17 \mathrm{kV}$ gun current) mounted on a Leica DM LM microscope.

Bulk samples were digested in 1:1:1 aqua regia and then analyzed for selected trace elements by ICP-MS at ACME Analytical Laboratories. Detection limits were: $0.2 \mathrm{ppb}$ for $\mathrm{Au} ; 2 \mathrm{ppb}$ for $\mathrm{Ag} ; 5 \mathrm{ppb}$ for $\mathrm{Hg} ; 0.01 \mathrm{ppm}$ for $\mathrm{Mo}, \mathrm{Cu}, \mathrm{Pb}$, and $\mathrm{Cd} ; 0.02 \mathrm{ppm}$ for $\mathrm{Bi}, \mathrm{Sb}, \mathrm{Tl}$, and Te; 0.1 ppm for Ni, Ga, Ge, Sn, Co, Zn, As, and Se; 1 ppm for Mn; and 0.01 wt \% for Fe.

\section{Regional and Local Geology}

Milos Island is a dormant volcanic center located in the central part of the Lower Pliocene to recent South Aegean active volcanic arc, which also includes the volcanic centers of Methana and Poros in its western part, and Santorini, Kos, and Nisyros in its eastern part (Figure 2a). The Aegean volcanic arc is generally considered a continental arc formed by the subduction of the African plate beneath the continental Aegean microplate [70-72]. Tertiary to Quaternary magmatism in the Aegean region occurred mostly in a post-collisional setting behind the active Hellenic subduction zone [71,73].

Volcanic activity in western Milos spans a period from $\sim 3.5 \mathrm{Ma}$ to present and originated from several emergent eruptive centers characterized by both explosive and effusive activities [74-77] (Figure 2b). Volcanic activity led to the deposition of shallow marine pumiceous tuffs and a calc-alkaline sequence of basalts, andesites, dacites, and rhyolites covered by alluvial sediments that both overlie an Upper Miocene to Lower Pliocene sedimentary sequence and a Mesozoic metamorphic basement of the Cycladic blueschist unit (Figure 2b) [74,78,79].

The volcanic units can be subdivided into four main phases and are (Figure $2 \mathrm{~b}$ ): (1) Lower to Upper Pliocene felsic submarine units including pumice-rich pyroclastics, intrusive rhyolitic subvolcanic bodies, and lavas in the western part of the island; (2) Upper Pliocene to Middle Pleistocene submarine pyroclastics and andesitic-dacitic flow domes and lavas, and submarine to subaerial dacitic-rhyodacitic flow banded domes associated with lithic- and pumice-rich pyroclastics in the western part of the island; (3) Lower to Middle Pleistocene submarine felsic domes-cryprodomes and pyroclastics, and subaerial rhyolitic lavas mainly in the eastern and northeastern parts of the island; and (4) Late Pleistocene subaerial explosive eruptions followed by rhyolitic lavas and accompanied by widespread phreatic activity, concentrated along the eastern coast of Milos Gulf on a well-defined NW-trending lineament.

Miocene to Pliocene extensional tectonics resulted in four main fault trends (NW-SE, N-S, NE-SW, and E-W) creating a series of horsts and graben structures controlling the volcanic and hydrothermal activity of the island until today (Figure $2 b$ ).

Paleochori Bay is located nearshore the southeast coast of Milos (Figure 2b). The socalled "green lahar" exposed onshore in the Paleochori area consists of volcanic ash with fragments of metamorphic, sedimentary, and volcanic rocks (Figure 2c). The seafloor at Paleochori Bay is covered by sandy volcaniclastic material with larger rock fragments towards the eastern and western coast. 


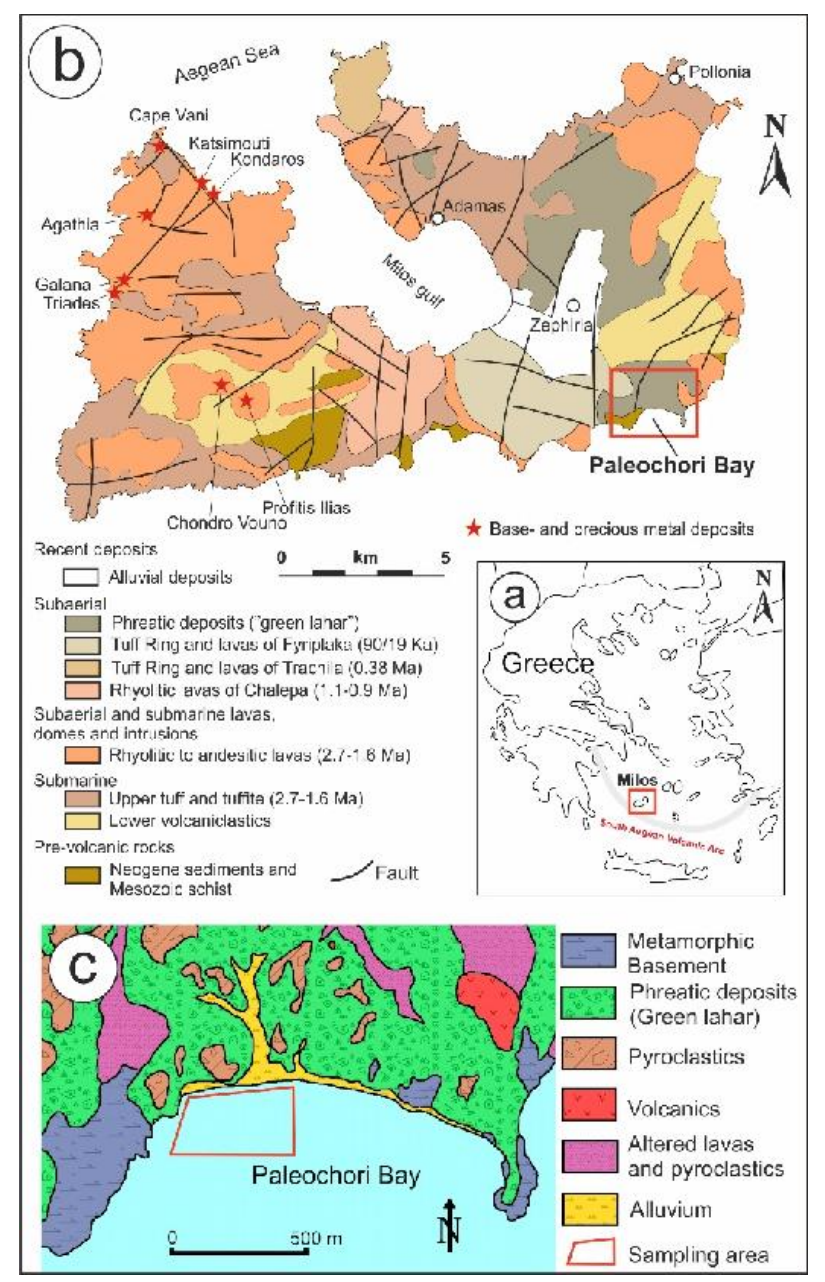

Figure 2. (a) Location of Milos island in the central part of the South Aegean Volcanic Arc; simplified geological map of (b) Milos island (modified from Fytikas et al. [74]; Stewart and McPhie [75], Alfieris et al. [58]; and Voudouris et al. [80]); and (c) of the Paleochori Bay showing sampling area (based on Kati et al. $[67,68])$.

\section{Hydrothermal Venting}

Venting activity around the eastern part of Milos island, including Paleochori Bay, occurs over an area of approximately $35 \mathrm{~km}^{2}$ from onshore to about $100 \mathrm{~m}$ water depth, and is characterized by gas- and liquid-dominated fluids that are emitted through the unconsolidated volcaniclastic cover $[40,41,45-47,50,53,63,81]$ (Figure 3). The hydrothermal fluids are highly sulfidic (up to $3 \mathrm{mM} \mathrm{H}_{2} \mathrm{~S}$ ) and reach temperatures of up to $122{ }^{\circ} \mathrm{C}[41,82]$. The active submarine hydrothermal system of Paleochori Bay discharges vapor- and liquiddominated aqueous fluids with average temperatures $\left(91 \pm 23^{\circ} \mathrm{C}\right)$. Vapors released from both subaerial fumaroles and submarine vents at the Paleochori Bay consist mainly of $\mathrm{CO}_{2}$ (55-92 vol. \%), $\mathrm{H}_{2}$ ( $<3$ vol. \%), $\mathrm{CH}_{4}\left(<10\right.$ vol. \%), and $\mathrm{H}_{2} \mathrm{~S}$ ( $<8$ vol. \%) [40]. Valsami-Jones et al. [41] and Wu et al. [28,44,45] identified two types of aqueous fluids at Paleochori Bay: (1) low-Cl fluids containing low concentrations of alkalis $(\mathrm{K}, \mathrm{Li}, \mathrm{Na})$ and $\mathrm{Ca}$, and high concentrations of silica and sulfate, as well as (2) high- $\mathrm{Cl}$ fluids containing high concentrations of alkalis and $\mathrm{Ca}$, and lower concentrations of silica and sulfate compared to seawater. High contents of $\mathrm{Zn}, \mathrm{Cd}, \mathrm{Mn}$, and $\mathrm{Pb}$ in the high- $\mathrm{Cl}$ fluids suggest that these metals are likely transported as chloride-complexes [41]. Both types of fluids occur next to each other in vents that are only a few meters apart discharging fluids with As concentrations of up 39 $\mu \mathrm{M}$ in the high- $\mathrm{Cl}$ fluids and up to $78 \mu \mathrm{M}$ in the low-Cl fluids [46]. These two fluid types at Paleochori Bay are interpreted to be vapor- and liquid-rich fractions that formed by boiling 
of deep reservoir $(\sim 1-2 \mathrm{~km})$ and shallow seawater-like fluids [28,41,45]. The low-Cl fluids are likely the result of vapor condensation into seawater in a steam-heated environment, whereas the high- $\mathrm{Cl}$ fluids are diluted in $\mathrm{Cl}$ as a result of seawater mixing [46].
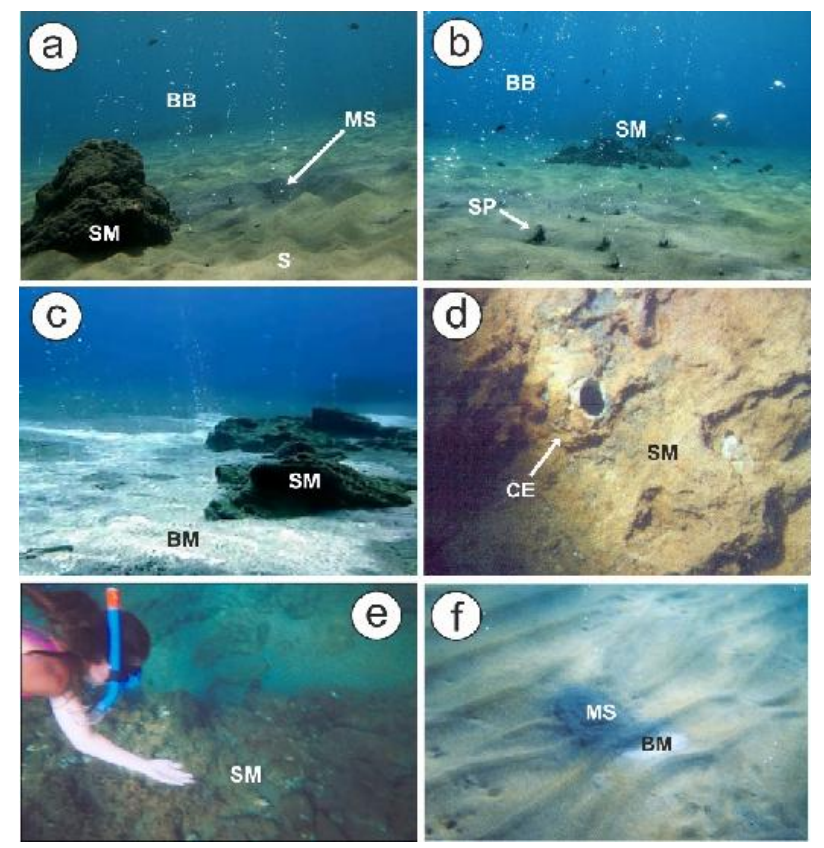

Figure 3. Features of hydrothermal venting through seafloor sediments $(S)$ at Paleochori Bay: $(\mathbf{a}-\mathbf{c})$ shallow-submarine venting associated with gas bubbles (BB) and the formation of metalliferous sediments (MS) and sulfide mounds (SM). The intensity of gas discharge is such that it raises sand plumes (SP). White bacteria mats (BM) are associated with venting (c). (d) Conical edifice (CE) (e.g., chimney) (approximately $3 \mathrm{~cm}$ diameter) discharging high-salinity liquids and no gas within an irregular shaped sulfide mound, from the hydrothermal fallout (photograph from Valsami-Jones et al. [41]); (e) sulfide mound (SM); (f) metalliferous sediments (MS), and white microbial mats (BM).

Hydrothermal activity with associated sulfide mineralization is concentrated in the center of the bay (Figures $2 c$ and 3). Intense streams of gas bubbles (Figure 3a-c) and high salinity liquid discharge (Figure 3d) emerge through the sandy seafloor or between sulfide mounds and conical edifices. According to Valsami-Jones et al. [41], venting associated with the formation of sulfide mounds from the hydrothermal fallout is also related to intermittent gas bubbling through the mound structure. Occasionally, the intensity of venting associated with gas bubbles is such that it raises grey to black sand plumes (fluid plumes with entrained sand) (Figure 3b).

Yellow, orange, white (Figure 3c,f), and brown patches on the sandy seafloor of several meters in diameter are associated with diffuse venting and the deposition of S- and As-rich substances and/or microbial mats [83-86]. The different colors correlate well to different seafloor temperatures and precipitate compositions, with the hottest areas $\left(>90^{\circ} \mathrm{C}\right) \mathrm{cov}$ ered mostly by yellow native sulfur and orange-colored sulfur/arsenic compounds and biogenic material [85]. White microbial mats occur throughout the bay and are associated with amorphous silica and native sulfur forming at lower temperatures $\left(\sim 45-85^{\circ} \mathrm{C}\right)$ [53]. Brown colored manganese and/or hydrous ferric oxide layers are related to the lowest hydrothermal temperature regime $\left(\sim 30-35{ }^{\circ} \mathrm{C}\right)[46,85]$. Microbial mats host chemolithotrophic sulfur oxidizing and sulfate-reducing microbes that facilitate the precipitation of various S-bearing mineral phases, including elemental S and Fe-sulfides (e.g., [50,86,87].

The shallow marine hydrothermal fluids discharging at Paleochori Bay are related to the active Milos geothermal field $[67,88]$, possibly representing a modern analogue to the onshore Profitis Ilias-Chondro Vouno epithermal Au-Ag mineralization [57]. Stable ( $\delta \mathrm{D}$ and 
$\left.\delta^{18} \mathrm{O}\right)$ and radiogenic isotope data $\left({ }^{87} \mathrm{Sr} /{ }^{86} \mathrm{Sr}\right)$, as well as $\mathrm{Br} / \mathrm{Cl}$ and $\mathrm{I} / \mathrm{Cl}$ ratios, suggest a seawater and meteoric water signature modified by water-rock interaction and fluid boiling in the geothermal fluids $[45,46,57,89]$.

\section{Results}

\subsection{Hydrothermal Precipitates}

The investigated samples represent different types of mineralization, including sulfide edifices with mound-like morphology and metalliferous sediments with sulfideencrustations in the immediate vicinity of areas with active fluid discharge (Figures 3 and 4, Table 1). Precipitate mineralogy and hydrothermal fluid composition (all fluid data from Valsami-Jones et al. [41]) vary between the sampling sites $(n=10)$ and with the mineralization-type (Table 1). Fluid temperature and $\mathrm{pH}$ range from $49^{\circ} \mathrm{C}$ to $110^{\circ} \mathrm{C}$ and 3.5 to 7.6 , respectively, at a water depth of $2.0 \mathrm{~m}$ to $4.5 \mathrm{~m}$ (Table 1 ).

Table 1. Characteristics of hydrothermal precipitates (this study) and fluids at Paleochori Bay. All fluid-and water-depth data are from Valsami-Jones et al. [41] and Wu et al. [44,45].

\begin{tabular}{|c|c|c|c|c|c|c|}
\hline Site & Sample No & Mineralization-Type & $\begin{array}{l}\text { Hydrothermal } \\
\text { Mineralogy }\end{array}$ & Fluid pH & Fluid $\mathrm{T}\left({ }^{\circ} \mathrm{C}\right)$ & Water Depth (m) \\
\hline 03-98 & ML03 & Sulfide mound & $\begin{array}{l}\text { Pyrite I, cinnabar, } \\
\text { marcasite }\end{array}$ & 7.6 & 107 & 4.1 \\
\hline \multirow[t]{3}{*}{$04-98$} & ML04 & Sulfide mound & $\begin{array}{l}\text { Pyrite II, } \\
\text { alunite-jarosite, barite }\end{array}$ & 5.6 & 110 & 3.8 \\
\hline & ML04A & $\begin{array}{l}\text { Metalliferous } \\
\text { sediment }\end{array}$ & Pyrite II & n.a. & n.a. & 4.1 \\
\hline & ML04B & $\begin{array}{l}\text { Metalliferous } \\
\text { sediment }\end{array}$ & Pyrite II & n.a. & n.a. & 4.1 \\
\hline $05-98$ & ML05 & Sulfide mound & $\begin{array}{l}\text { Pyrite II, marcasite, } \\
\text { alunite-jarosite }\end{array}$ & 5.2 & 72.5 & 3.9 \\
\hline 06-98 & ML06 & $\begin{array}{l}\text { Metalliferous } \\
\text { sediment }\end{array}$ & Pyrite I & 6.0 & 111 & 4.0 \\
\hline 07-97 & ML07A & Sulfide mound & $\begin{array}{l}\text { Pyrite II, alunite, } \\
\text { Sr-barite }\end{array}$ & 3.5 & 97 & 2.2 \\
\hline $11-97$ & ML11A & Sulfide mound & $\begin{array}{l}\text { Pyrite II, } \\
\text { alunite-jarosite, barite }\end{array}$ & 5.1 & 49 & 2.6 \\
\hline $22-97$ & ML22B & Sulfide mound & Pyrite II, barite & 5.7 & 74.1 & 4.3 \\
\hline \multirow[t]{3}{*}{$27-96$} & ML27C & Sulfide mound & $\begin{array}{l}\text { Pyrite I, Mn-calcite, } \\
\text { barite }\end{array}$ & 6.3 & n.a. & 2.5 \\
\hline & ML27CC & Sulfide mound & Pyrite I, Sr-barite & n.a. & n.a. & 2.5 \\
\hline & ML27D & Sulfide mound & $\begin{array}{l}\text { Pyrite II, } \\
\text { alunite-jarosite, barite }\end{array}$ & n.a. & n.a. & 4.0 \\
\hline $28-96$ & ML28C & Sulfide mound & $\begin{array}{l}\text { Pyrite I, Mn-calcite, } \\
\text { gypsum }\end{array}$ & 6.5 & 95 & 2.5 \\
\hline \multirow[t]{3}{*}{$38-96$} & ML38A & Sulfide mound & Pyrite I, barite, calcite & 7.1 & 105 & 2.5 \\
\hline & ML38B & Sulfide mound & $\begin{array}{l}\text { Pyrite I, Mn-calcite, } \\
\text { barite }\end{array}$ & n.a. & n.a. & 2.5 \\
\hline & ML38C & Sulfide mound & $\begin{array}{l}\text { Pyrite I, Mn-calcite, } \\
\text { barite, gypsum }\end{array}$ & n.a. & n.a. & 2.5 \\
\hline
\end{tabular}

n.a. = not available. For definition of pyrite I and II, see text.

The precipitates are associated with different styles of fluid discharge including venting associated with high-salinity liquids and/or gas bubbles and leading to the formation of small mound-like structures (Figure 3). The sulfide mounds form solid irregular edifices up to $0.5 \mathrm{~m}$ high and $1 \mathrm{~m}$ wide, locally including chimney-like structures (e.g., conical edifices) (Figure 3a-e). The mounds are breccia structures consisting of detrital siliceous grains (e.g., sand grains of volcaniclastic sands), cemented by hydrothermal minerals, mostly a pyrite matrix (Figure 4a,b). Locally, a good development of colloform bands of 
pyrite and/or marcasite occurs (Figure 4c). Small cracks act as pathways for vigorous bubbling and fluid discharge, some of which are sealed by sulfide deposition.

The metalliferous sediments occur on the seafloor in areas of active fluid discharge through volcaniclastic material (Figure $3 \mathrm{a}, \mathrm{b}, \mathrm{f}$ ), where they locally also cover the mounds. The metalliferous sediments form individual hydrothermal blackish precipitates on the sandy seafloor, and/or discontinuous sulfide-bearing encrustations on the surfaces of loose sand fragments (Figure $4 \mathrm{~d}$,e). Similarly, larger detrital rock fragments (up to several $\mathrm{cm}$ in size) host sulfides (mostly pyrite and marcasite) as coatings and encrustations ( 1-3 mm) (Figure 4f). Based on in situ observations, all or parts of these structures are annual features, which grow during the summer, and collapse in the winter as a result of rough weather [41].

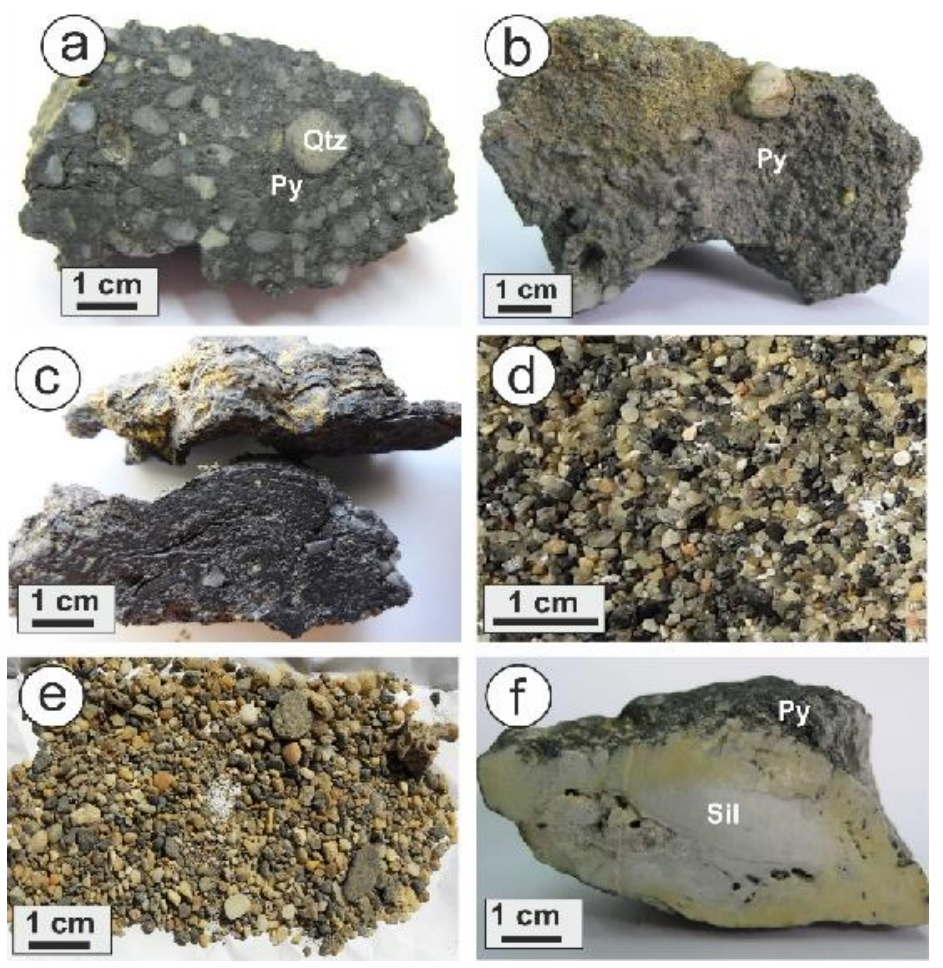

Figure 4. Representative examples of the different mineralization types (samples of sulfide-mounds and metalliferous sediments correspond to hydrothermal features shown in Figure 3): (a,b) Hand specimens of sulfide-coated mounds; pyrite (Py) cements clastic quartz (Qtz) grains (ML04 and ML05 respectively); (c) hand specimen of sulfide mound consisting of colloform cinnabar-bearing pyrite/marcasite layers cementing clastic quartz grains (ML03); (d,e) unconsolidated metalliferous sediments from areas with active fluid discharge (ML04A and ML04B, respectively); (f) fragment of metalliferous sediment, where sulfide encrustations composed of pyrite surround opaline silicified rocks (Sil) (ML06).

\subsection{Bulk Ore Geochemistry}

Bulk sulfide analyses of the different mineralization types at Paleochori Bay (Table 2) generally indicate high concentrations in elements like As (up to $2587 \mathrm{ppm}$ ), Mn (up to $2360 \mathrm{ppm}$ ), $\mathrm{Co}$ (up to $813 \mathrm{ppm}$ ), $\mathrm{Tl}$ (up to $513 \mathrm{ppm}$ ), Sb (up to $274 \mathrm{ppm}$ ), and $\mathrm{Hg}$ (up to $34 \mathrm{ppm}$ ). Chimney-like structures tend to be enriched in most trace elements including $\mathrm{Fe}, \mathrm{Mn}, \mathrm{As}, \mathrm{Hg}, \mathrm{Cu}, \mathrm{Pb}$, and $\mathrm{Zn}$ compared to the metalliferous sediments (Table 2 and Figure 5). This is likely due to higher sulfide abundances in the chimneys or a dilution by the more abundant detrital material in the sediments. 
Table 2. Bulk ore analyses (ICP-MS) of sulfide samples from Paleochori Bay. Iron in wt \%, Au and $\mathrm{Ag}$ in ppb, and all other elements in ppm. Sample numbers, as in Figure 4 and Table 1.

\begin{tabular}{cccccc}
\hline Sample & ML03 & ML05 & ML04A & ML04B & ML06 \\
\hline Element & Sulfide & Sulfide & Metalliferous & Metalliferous & Metalliferous \\
Mound & Mound & Sediment & Sediment & Sediment \\
\hline $\mathrm{Fe}$ & 27.06 & 15.36 & 1.24 & 0.99 & 2.06 \\
$\mathrm{As}$ & 736.0 & 2587 & 92.6 & 116.1 & 411.0 \\
$\mathrm{Bi}$ & 0.16 & 0.08 & 0.14 & 0.12 & 0.04 \\
$\mathrm{Cd}$ & 0.22 & 0.19 & 0.03 & 0.03 & 0.05 \\
$\mathrm{Co}$ & 44.8 & 111 & 813.2 & 204.6 & 237.8 \\
$\mathrm{Cu}$ & 32.24 & 21.55 & 8.82 & 6.38 & 10.33 \\
$\mathrm{Ga}$ & 2.1 & 1.5 & 2.2 & 1.0 & 0.1 \\
$\mathrm{Ge}$ & 0.2 & 0.2 & $<0.1$ & $<0.1$ & $<0.1$ \\
$\mathrm{Hg}$ & 33.73 & 4.62 & 0.54 & 0.50 & 0.44 \\
$\mathrm{Mn}$ & 2362 & 559 & 193 & 305 & 58 \\
$\mathrm{Mo}$ & 8.82 & 6.54 & 2.75 & 2.07 & 2.14 \\
$\mathrm{Ni}$ & 64.1 & 78.8 & 54.5 & 23.2 & 11.62 \\
$\mathrm{~Pb}$ & 13.88 & 17.56 & 7.07 & 5.57 & 1.90 \\
$\mathrm{Sb}$ & 6.18 & 14.12 & 3.55 & 274.3 & 0.2 \\
$\mathrm{Se}$ & 1.2 & 0.8 & $<0.1$ & 0.1 & 1.0 \\
$\mathrm{Sn}$ & 4.2 & 2.8 & 0.1 & 0.1 & 0.06 \\
$\mathrm{Te}$ & 0.18 & 0.07 & $<0.02$ & 0.08 & 17.7 \\
$\mathrm{Zn}$ & 83.4 & 76.4 & 25.2 & 11.3 & 110 \\
$\mathrm{Ag}$ & 185 & 103 & 119 & 119 & 2.2 \\
$\mathrm{Au}$ & 22.6 & 13.0 & 2.9 & 10.8 & \\
\hline & & & & & \\
\hline
\end{tabular}
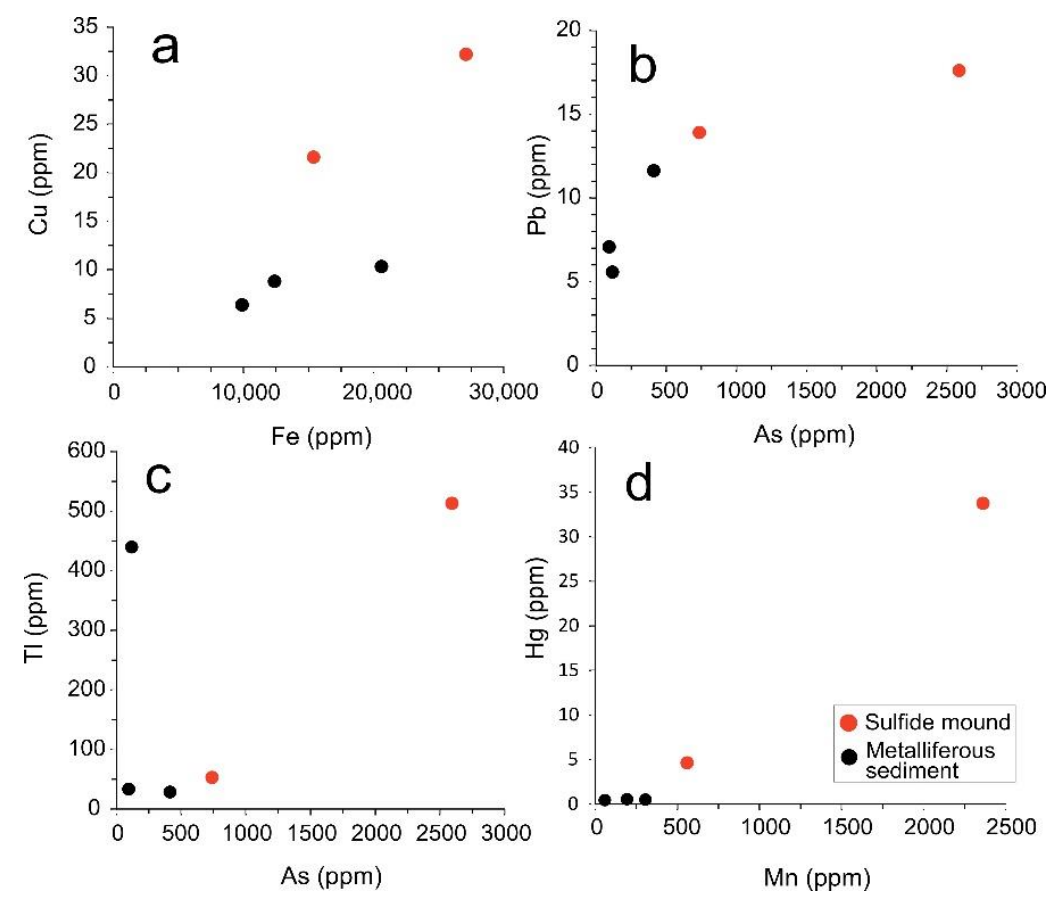

Figure 5. Bulk ore correlation diagrams of mineralized samples from Paleochori Bay: (a) Fe-Cu; (b) As-Pb; (c) As-Tl; (d) Mn-Hg.

\subsection{Mineralogy}

The mound-like structures and the metalliferous sediments are heterogeneous on a small scale $(\sim 1 \mathrm{~cm})$. However, the sulfides of both mineralization styles display similar textural and temporal relationships. The main framework material consists of volcaniclastic sandstones including fragments of hydrothermal altered and mineralized volcanic and 
metamorphic country rock, which are mostly cemented by sulfides like pyrite and marcasite (Figure $6 \mathrm{a}-\mathrm{c}$ ) or by other hydrothermal precipitates like barite and calcite (Figure 6a,d).
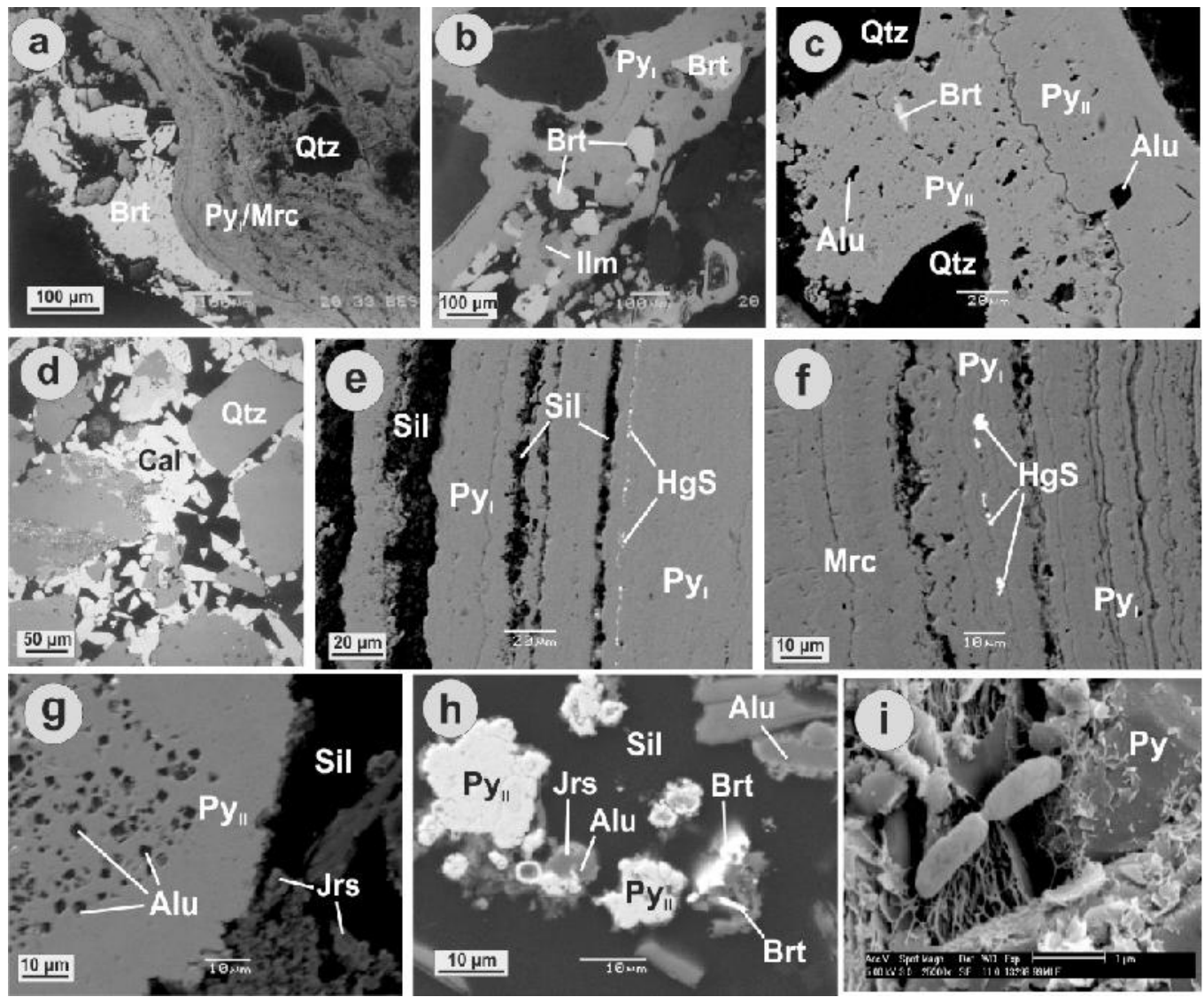

Figure 6. Backscattered (a-h) and secondary (i) electron images of sulfide edifices from Paleochori Bay (samples as in Tables 1 and 2): (a) hydrothermal barite (Brt) surrounding colloform pyrite/marcasite (Py I/Mrc), and detrital quartz (Qtz) grains (ML03); (b) colloform pyrite (Py I) surrounding and cementing barite (Brt) and ilmenite (Ilm) (ML03); (c) detrital quartz surrounded by massive pyrite (Py II) hosting alunite (Alu) and barite (ML04); (d) detrital quartz cemented by hydrothermal Mn-rich calcite (Cal) (ML28C); (e,f) cinnabar (HgS) microlayers within colloform pyrite/marcasite (Py I) alternating with bands of amorphous silica (Sil) (ML03); (g) natrojarosite (Jrs) surrounding pyrite (Py II) hosting pseudocubic grains of alunite (ML05); (h) subhedral and minor framboidal pyrite associated with barite, amorphous silica, alunite, and natrojarosite (ML04); and (i) microbial cells showing division (implying active growth), attached to pyrite. Honeycomb organic structures are in between pyrite and microbes (ML27C).

The detrital material mostly consists of quartz, feldspars (commonly intensely altered), muscovite, biotite, chlorite, rutile, and titanite, as well as subordinate clasts of mica schists, volcaniclastics, and microcrystalline silica reflecting the country rock of Paleochori Bay. The iron sulfide cements are texturally diverse occurring mostly as massive or laminated colloform layers of pyrite/marcasite intergrowth locally with high porosity, cementing detrital material (Figure 6). In addition, minor euhedral pyrite associated with calcite in the pore space locally surrounds colloform pyrite/marcasite and framboidal pyrite. Two types of pyrite mineralization generally occur at Paleochori Bay (Figures 6 and 7), including colloform pyrite (Py I), which is associated with calcite and apatite (Figure 7), as well as massive pyrite (Py II) that is associated with barite, alunite, and amorphous silica (Figure 6c,g,h).

In the absence of colloform pyrite, calcite appears to be the first mineral cementing the sediments (Figure 6d), which is locally followed by gypsum mineralization. In contrast, 
in the absence of calcite, pyrite cement is followed by yellow-colored spherulitic aggregates of zeolites associated with clays and Fe-hydroxides. Silica commonly occurs as amorphous to cryptocrystalline quartz together with cinnabar forming microlayers (up to $3 \mu \mathrm{m}$ ) alternating with colloform pyrite/marcasite (Py I) bands (Figure 6e,f). In addition, native sulfur was identified in the chimney- and mound-like structures, which also occurs together with orpiment in microbial mats on the seafloor $[46,48]$. Microbe cells have been found attached to the sulfide precipitates (Figure 6i). The cells appear to be dividing and excreting a framework of honeycomb-like structures with conditioning polymers around them, both indicating that the microbes are thriving in the vent water and pyritic depositional environment. These microbes may contain high levels of arsenic [85].
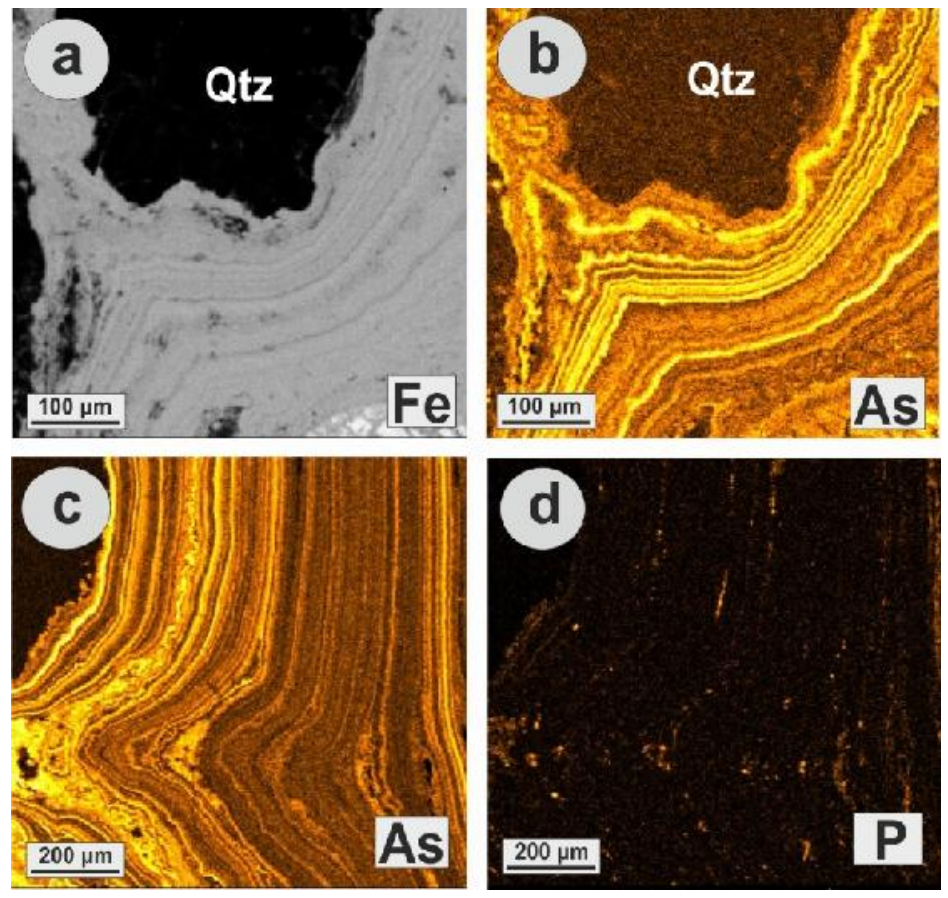

Figure 7. X-ray element mapping showing the distribution of Fe-As (a,b), and As and P (c,d) in colloform pyrite I. Positive P anomalies in pyrite are related to micro-inclusions of apatite (ML27CC).

\subsection{Hydrothermal Mineral Paragenesis}

At Paleochori Bay, the sulfide mineralization is marked by two distinct mineral assemblages (Figure 8). The formation of As-rich colloform pyrite/marcasite (Py I) is related to the occurrence of cinnabar micro-layers in the colloform textures also suggesting a contemporaneous deposition. Manganese-bearing calcite and apatite also form together with early pyrite/marcasite I, filling interstitial spaces. Massive pyrite II represents the second pyrite generation that contemporaneously formed with barite, gypsum, alunitejarosite, hydrothermal silica, and Fe-hydroxides. Pyrite II could be additionally divided in sub-assemblages, as indicated by textural and morphological features shown in Figure 6c,g, and also supported by Figure 9. However, they are unified here for simplicity reasons, and will be studied in detail in a future paper related to their forming conditions. Although not observed, it is most likely that cinnabar also associates with massive pyrite II together with alunite.

\subsection{Mineral-Chemistry}

Pyrite is the dominant sulfide and accounts for $>70$ volume $\%$ of the total sulfide mineral content in all types of hydrothermal precipitates, followed by marcasite as the second most abundant sulfide. Electron microprobe analyses revealed a large variation in the chemical composition of pyrite/marcasite ranging from near stoichiometric compositions to elevated As (up to $3.2 \mathrm{wt} \%$ ) and Mn (up to $0.4 \mathrm{wt} \%$ ) in colloform pyrite/marcasite 
(Py I) and up to $1.7 \mathrm{wt} \%$ As and $0.6 \mathrm{wt} \% \mathrm{Mn}$ in massive pyrite (Py II) (Table 3 and Figure 7). Cobalt and Ni occur in minor amounts reaching $0.1 \mathrm{wt} \%$ (Table 3). Arsenic-rich colloform pyrite/marcasite (Py I) exhibits a negative correlation between arsenic and sulfur in sample ML38A, suggesting that arsenic substitutes for sulfur in the pyrite lattice (Figure 9a) [90-92]. In contrast, a negative correlation exists between arsenic and iron in alunite-associated pyrite II of sample ML22B (Figure 9b). Although pyrite from sample ML11A is also alunite-associated, the negative Fe-As relationship is less well developed and As contents are generally very low $(<0.2 \mathrm{wt} \%$; Table 3$)$. Cinnabar $(\mathrm{HgS})$ typically occurs as micro-layers in colloform pyrite/marcasite I (Figure 6e,f), and hence elevated Fe contents in cinnabar (up to $7.0 \mathrm{wt} \%$ ) are likely caused by an interaction of the electron beam with the pyrite/marcasite host.

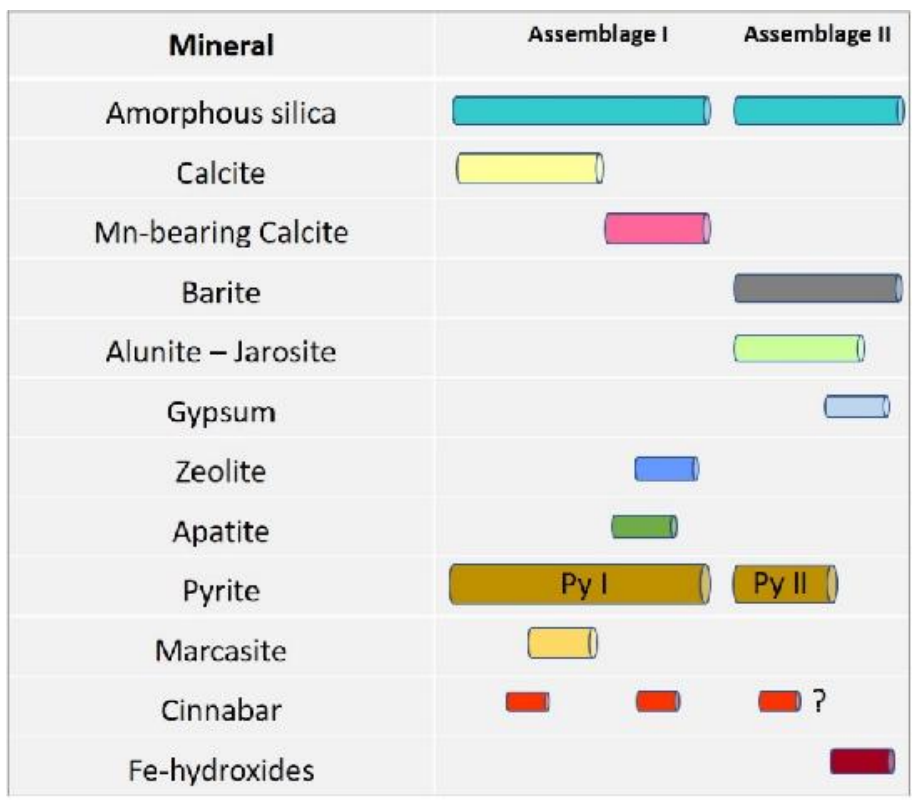

Figure 8. Paragenetic sequence of hydrothermal mineralization at Paleochori Bay. Thickness of the bars indicate relative minerals abundances.
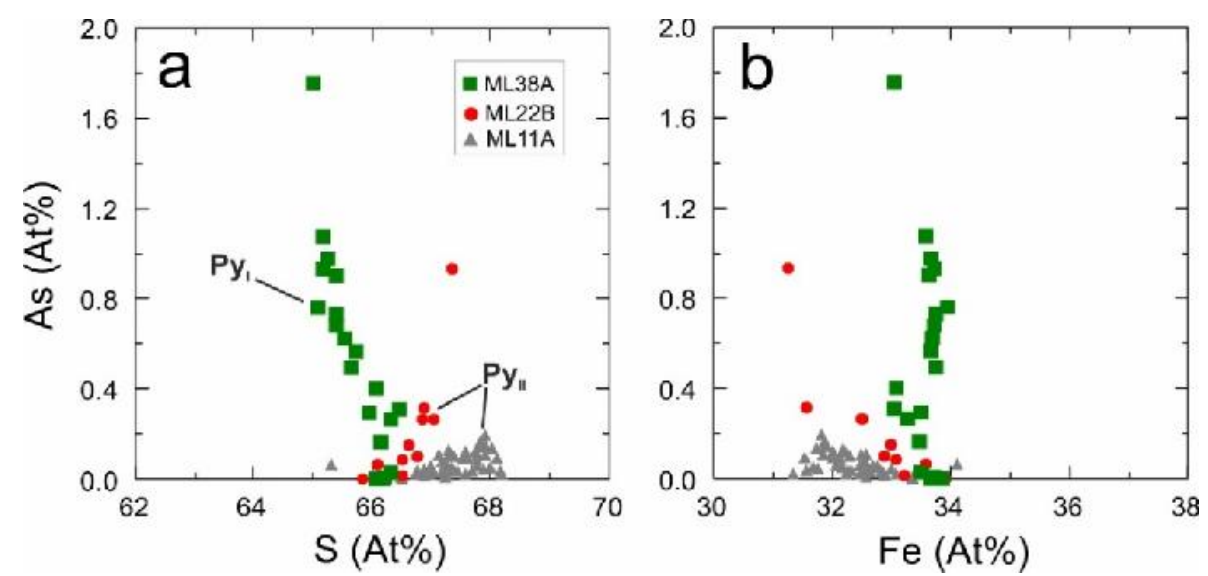

Figure 9. Chemical variations of colloform pyrite I (ML38A) and massive pyrite II (ML22B, ML11A) as a function of (a) As-S and (b) As-Fe. 
Table 3. Representative electron microprobe analyses of pyrite (1-14) and cinnabar (15-16) from Paleochori. Concentrations in wt \%. For the full dataset please refer to supplementary Table S1.

\begin{tabular}{|c|c|c|c|c|c|c|c|c|c|c|c|c|c|c|c|c|}
\hline Element & 1 & 2 & 3 & 4 & 5 & 6 & 7 & 8 & 9 & 10 & 11 & 12 & 13 & 14 & 15 & 16 \\
\hline $\mathrm{Fe}$ & 46.26 & 45.96 & 46.01 & 47.15 & 46.73 & 44.82 & 46.08 & 46.06 & 45.35 & 46.18 & 43.13 & 47.53 & 44.97 & 45.14 & 4.28 & 6.79 \\
\hline $\mathrm{Co}$ & 0.01 & 0.01 & 0.14 & 0.01 & 0.01 & 0.14 & 0.05 & 0.07 & 0.02 & 0.11 & b.d.l. & 0.03 & 0.10 & 0.10 & b.d.l. & b.d.l. \\
\hline $\mathrm{Ni}$ & 0.03 & b.d.l. & 0.07 & b.d.l. & 0.03 & b.d.l. & b.d.l. & 0.11 & b.d.l. & 0.01 & 0.01 & 0.01 & b.d.l. & 0.13 & b.d.l. & b.d.l. \\
\hline $\mathrm{Cu}$ & b.d.l. & b.d.l. & 0.04 & b.d.l. & 0.11 & 0.03 & b.d.l. & 0.09 & 0.05 & 0.03 & b.d.l. & 0.08 & 0.04 & b.d.l. & b.d.l. & b.d.l. \\
\hline $\mathrm{Zn}$ & b.d.l. & 0.10 & 0.03 & 0.11 & b.d.l. & 0.12 & 0.21 & b.d.l. & b.d.l. & b.d.l. & b.d.l. & 0.04 & 0.07 & 0.04 & b.d.l. & b.d.l. \\
\hline $\mathrm{Hg}$ & - & - & - & - & - & - & - & - & - & - & - & - & - & - & 79.06 & 73.25 \\
\hline Mn & 0.16 & 0.13 & 0.37 & b.d.l. & 0.01 & b.d.l. & 0.02 & b.d.l. & 0.52 & 0.18 & 0.62 & 0.22 & 0.10 & 0.16 & b.d.l. & b.d.l. \\
\hline As & 1.35 & 0.49 & 0.75 & 0.02 & 0.93 & 3.20 & 1.99 & 1.71 & 0.50 & 0.29 & 1.72 & b.d.l. & 0.15 & 0.11 & b.d.l. & b.d.l. \\
\hline$S$ & 51.50 & 52.62 & 52.76 & 53.16 & 52.19 & 50.63 & 51.33 & 51.11 & 53.59 & 53.54 & 53.37 & 53.00 & 53.29 & 53.13 & 17.82 & 19.45 \\
\hline Total & 99.31 & 99.30 & 100.16 & 100.45 & 100.00 & 98.94 & 99.68 & 99.15 & 100.03 & 100.34 & 98.85 & 100.92 & 98.70 & 98.81 & 101.16 & 99.49 \\
\hline \multicolumn{15}{|c|}{ Structural formula on the basis of $2 \mathrm{~S} \mathrm{pfu}$} & \multicolumn{2}{|c|}{$3 \mathrm{apfu}$} \\
\hline $\mathrm{Fe}$ & 1.032 & 1.003 & 1.001 & 1.018 & 1.028 & 1.017 & 1.031 & 1.035 & 0.972 & 0.990 & 0.928 & 1.030 & 0.969 & 0.976 & 0.149 & 0.222 \\
\hline Co & & & 0.003 & & & 0.003 & 0.001 & 0.002 & & 0.002 & & 0.001 & 0.002 & 0.002 & & \\
\hline $\mathrm{Ni}$ & 0.001 & & 0.002 & & 0.001 & & & 0.002 & & & & & & 0.003 & & \\
\hline $\mathrm{Cu}$ & & & 0.001 & & 0.002 & 0.001 & & 0.002 & 0.001 & 0.001 & & 0.002 & 0.001 & & & \\
\hline $\mathrm{Zn}$ & & 0.002 & & 0.002 & & 0.002 & 0.004 & & & & & 0.001 & 0.001 & 0.001 & & \\
\hline $\mathrm{Hg}$ & - & - & - & - & - & - & - & - & - & - & - & - & - & - & 0.768 & 0.668 \\
\hline Mn & 0.004 & 0.003 & 0.008 & & & & & & 0.011 & 0.004 & 0.014 & 0.005 & 0.002 & 0.004 & & \\
\hline As & 0.022 & 0.008 & 0.012 & & 0.015 & 0.054 & 0.033 & 0.029 & 0.008 & 0.005 & 0.028 & & 0.002 & 0.002 & & \\
\hline
\end{tabular}

1-8: ML38A (Py-I); 9-12: ML22B (Py II); 13,14: ML11A (Py II); 15,16: ML03. (-): not analyzed; b.d.l. = below detection limit.

Calcite associated with colloform pyrite/marcasite (Py I) and euhedral pyrite shows elevated $\mathrm{MnO}$ contents (up to $5.9 \mathrm{wt} \%$ ), as well as minor amounts of $\mathrm{MgO}$ (up to $0.34 \mathrm{wt} \%$ ) and $\mathrm{FeO}$ (up to $1.1 \mathrm{wt} \%$ ) (Supplementary Table S2). Mapping of barite by EDS displays Sr-rich barite rims (up to 8.7 wt \% SrO) (Supplementary Table S2), replacing Sr-poor barite cores of near stoichiometric composition (Figure 10). The Sr-rich rims in barite indicate a composition of the barite-celestine solid solution series [93], which is closely associated with massive pyrite (Py II) (Figures 6 and 10).
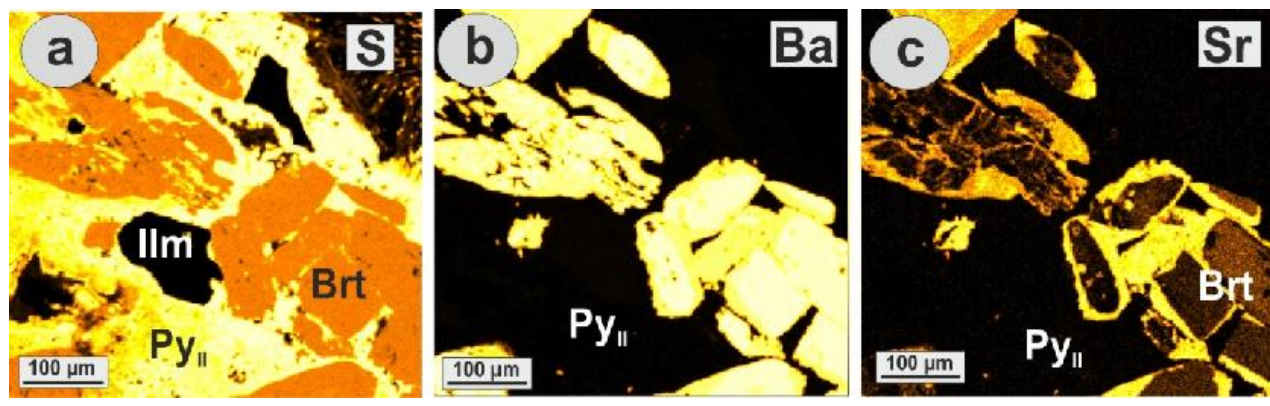

Figure 10. EDS maps of (a) S, (b) Ba and (c) Sr from a pyrite (Py)-barite (Brt)-Ilmenite (Ilm) assemblage, showing significant variations of $\mathrm{Sr}$ between barite cores and rims (ML7A).

Alunite group minerals (Figure $6 \mathrm{c}, \mathrm{g}, \mathrm{h}$ ) at Paleochori Bay are present as solid solutions between alunite/natroalunite and jarosite/natrojarosite (Table 4, Figure 11) (e.g., [94]). The alunite-jarosite solid solutions at Paleochori are characterized by varying content in $\mathrm{Al}_{2} \mathrm{O}_{3}\left(4.97-31.58\right.$ wt \%), $\mathrm{Fe}_{2} \mathrm{O}_{3}\left(0.90-34.73\right.$ wt \%), $\mathrm{K}_{2} \mathrm{O}\left(0.45-7.40\right.$ wt \%), and $\mathrm{Na}_{2} \mathrm{O}$ (0.43-5.97 wt \%). 
Table 4. Representative microanalyses of alunite (1-5), natroalunite (6), alunite-jarosite solid solution (7), natrojarosite (8-10).

\begin{tabular}{|c|c|c|c|c|c|c|c|c|c|c|}
\hline Wt.\% & 1 & 2 & 3 & 4 & 5 & 6 & 7 & 8 & 9 & 10 \\
\hline $\mathrm{K}_{2} \mathrm{O}$ & 6.78 & 6.70 & 8.16 & 6.72 & 7.92 & 2.83 & 4.02 & 1.99 & 2.69 & 1.26 \\
\hline $\mathrm{Na}_{2} \mathrm{O}$ & 1.07 & 0.86 & 1.01 & 1.75 & 1.11 & 3.77 & 1.70 & 6.25 & 5.31 & 6.33 \\
\hline $\mathrm{CaO}$ & b.d.l. & b.d.l. & 0.12 & 0.06 & 0.30 & 0.07 & b.d.l. & 0.14 & b.d.l. & 0.05 \\
\hline $\mathrm{Al}_{2} \mathrm{O}_{3}$ & 34.02 & 33.81 & 30.92 & 32.74 & 34.35 & 30.56 & 19.91 & 8.64 & 15.54 & 11.49 \\
\hline $\mathrm{SiO}_{2}$ & b.d.l. & b.d.l. & b.d.l. & 4.30 & 2.03 & 5.71 & 2.80 & 1.92 & b.d.l. & 2.02 \\
\hline $\mathrm{Fe}_{2} \mathrm{O}_{3}$ & 1.55 & 3.49 & 5.91 & 0.92 & 2.08 & 4.62 & 22.55 & 33.03 & 27.96 & 31.02 \\
\hline $\mathrm{SO}_{3}$ & 37.47 & 39.19 & 39.16 & 37.43 & 37.87 & 36.78 & 33.26 & 34.29 & 33.32 & 34.12 \\
\hline $\mathrm{P}_{2} \mathrm{O}_{5}$ & 2.66 & 1.70 & 0.13 & b.d.l. & 0.64 & 0.08 & 0.02 & 0.10 & 1.61 & b.d.l. \\
\hline Total & 83.55 & 85.75 & 85.44 & 83.93 & 86.31 & 84.42 & 84.26 & 86.36 & 86.43 & 86.33 \\
\hline \multicolumn{11}{|c|}{ Structural formula on the basis of $11(\mathrm{O})$} \\
\hline $\mathrm{K}$ & 0.653 & 0.624 & 0.787 & 0.647 & 0.752 & 0.268 & 0.420 & 0.216 & 0.286 & 0.134 \\
\hline $\mathrm{Na}$ & 0.157 & 0.122 & 0.146 & 0.257 & 0.163 & 0.548 & 0.268 & 1.015 & 0.852 & 1.021 \\
\hline $\mathrm{Ca}$ & & & 0.012 & 0.006 & 0.023 & 0.006 & & 0.012 & & 0.006 \\
\hline $\mathrm{Al}$ & 3.033 & 2.922 & 2.747 & 2.905 & 2.998 & 2.701 & 1.931 & 0.852 & 1.517 & 1.126 \\
\hline $\mathrm{Si}$ & & & & 0.327 & 0.152 & 0.426 & 0.227 & 0.157 & & 0.169 \\
\hline $\mathrm{Fe}^{3+}$ & 0.087 & 0.192 & 0.338 & 0.052 & 0.117 & 0.262 & 1.394 & 2.082 & 1.738 & 1.937 \\
\hline$S$ & 2.123 & 2.170 & 2.217 & 2.117 & 2.112 & 2.071 & 2.053 & 2.158 & 2.065 & 2.123 \\
\hline $\mathrm{P}$ & 0.169 & 0.105 & 0.006 & 0.000 & 0.041 & 0.006 & 0.000 & 0.006 & 0.111 & 0.000 \\
\hline
\end{tabular}

b.d.l. = below detection limit (sample ML05).

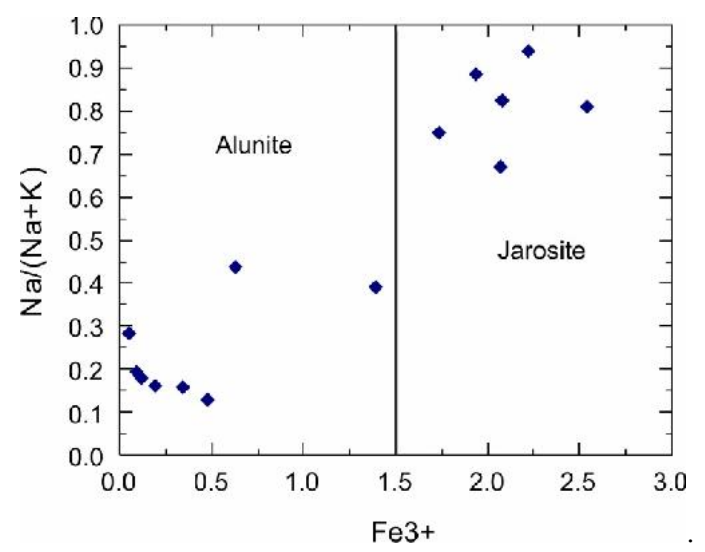

Figure 11. Chemical variation of alunite-jarosite solid solution minerals from Paleochori vents as a function of $\mathrm{Na} /(\mathrm{Na}+\mathrm{K})$ relative to $\mathrm{Fe}^{3+}$.

\section{Discussion}

\subsection{Interpretation on Mineral Paragenesis}

The two distinct pyrite assemblages at Paleochori Bay reflect distinct precipitation conditions with respect to temperature, $\mathrm{pH}$ and $\mathrm{fO}_{2}$. The formation of As-rich colloform pyrite/marcasite (Py I) (Figures 6-8) is typically related to disequilibrium conditions reflecting rapid crystallization due to abundant fluid-seawater mixing $[9,10,95]$. This early stage process cements the detrital material (Figure 6a-d) and insulates the fluid pathways from ambient seawater for subsequent precipitation in a more stable fluid environment, as reflected by later minor euhedral pyrite. These early processes are comparable to many other submarine hydrothermal systems and seem to be unaffected by water depth $[9,10,39,95,96]$.

The alternation of pyrite/marcasite in the early colloform textures indicates fluctuations in the physicochemical composition of the hydrothermal fluids, as indicated by marcasite precipitation at lower $\mathrm{pH}$ and temperature relative to pyrite [97]. At Luise Harbor, Lihir Island, $\mathrm{pH}$ variations due to mixing between vapor-dominated fluids and seawater in variable proportions are likely to be responsible for the alternating deposition of pyrite and marcasite, where marcasite requires lower $\mathrm{pH}$ conditions than pyrite [30]. Alternatively, the pyrite/marcasite alternations at Paleochori Bay may be caused by fluid 
temperature fluctuations as a result of variable proportions of fluid-seawater mixing leading to marcasite deposition at lower temperatures $[9,97]$. Relatively large fluctuations of vent temperatures in Paleochori Bay occur at tidal frequencies and seismic events [98]. Abrupt fluctuations in fluid chemistry may be responsible for the alternation of the As-rich (up to $3.2 \mathrm{wt} \%$ ) and As-poor layers in the colloform pyrite/marcasite I (Figure 7) indicating changes of the As content of the precipitating fluids.

The second pyrite generation (Py II) formed contemporaneously with alunite/natroalunite, jarosite/natrojarosite, hydrothermal silica, and Fe-hydroxides (Figures 6, 8 and 10). The latter may be related to a supergene oxidation of the Fe-sulfides by seawater $[9,95,99]$. The paragenetic sequence (Figure 8) and the observed As variations in pyrite relative to Fe and S (Figure 9) probably reflect temporal or local changes in the chemistry of the hydrothermal fluids $[9,100]$.

\subsection{Formation of Arsenian Pyrite}

Arsenian pyrite is a common constituent in epithermal systems and formation of arsenian pyrite may be the key to the formation of many Au deposits, in which pyrite can be an important and often undervalued host for $\mathrm{Au}$ [92,100-107]. Two main types of arsenian pyrite are usually distinguished: (1) $\mathrm{As}^{1-}$ pyrite, in which $\mathrm{As}^{1-}$ substitutes for $\mathrm{S}$ reflected by a negative correlation of As and $S$ typically found in Carlin-type and low-sulfidation epithermal deposits (e.g., [90]), and (2) $\mathrm{As}^{2+/ 3+}$ pyrite, in which oxidized As species substitute for Fe leading to a negative As-Fe relationship commonly related to high-sulfidation epithermal conditions, due to their more oxidized character [92,100,106,108,109]. Alternatively, As can occur as amorphous As-Fe-S nanoparticles in As-rich pyrite, suggesting the presence of $\mathrm{As}^{0}$ species [105]. Accordingly, the As-Fe-S ternary diagram provides information on the As incorporation and speciation in pyrite either as $\mathrm{As}^{1-}, \mathrm{As}^{2+/ 3+}$, or $\mathrm{As}^{0}[91,92,109]$. The As-Fe-S ternary diagram (Figure 12), suggests that $\mathrm{As}^{1-}$ substitutes for $\mathrm{S}$ in colloform pyrite/marcasite (Py I) associated with calcite at Paleochori Bay, in accordance to the As vs. S scatterplot (Figure 9). The As-Fe-S ternary diagram also suggests the possible occurrence of massive $\mathrm{As}^{3+}$ pyrite (Py II), as well as a substitution of $\mathrm{Fe}^{2+}$ by $\mathrm{Me}^{2+}$ leading to the incorporation of other divalent trace elements in pyrite II that is associated with alunite at Paleochori (Figure 12). The different As incorporation in pyrite II could reflect changes in forming conditions. However the exact substitution mechanisms and the specific geochemical conditions of formation at Paleochori Bay, cannot be resolved based on available data, and will be the subject of a future study.

The $\mathrm{As}^{1-}$ incorporation in colloform pyrite/marcasite I suggests more reducing lowsulfidation hydrothermal conditions (e.g., [110]) and is compatible with its calcite and apatite association in the chimney- and mound-like structures at Paleochori. Low sulfidation conditions are usually also characterized by lower fluid temperatures and neutral to alkaline $\mathrm{pH}$ conditions [111] indicating that marcasite precipitation at Paleochori Bay is thought to be due to temperature fluctuation, rather than being caused by decreasing to more acidic $\mathrm{pH}$ [97]. In contrast, massive $\mathrm{As}^{3+}$-pyrite II formation in the mounds, implies more oxidizing and lower $\mathrm{pH}$ conditions, as also reflected by its association with alunite (e.g., [111]). The lower $\mathrm{pH}$ conditions suggested for the pyrite II-related fluids could also explain the As depletion in these pyrites relative to the colloform $\mathrm{As}^{1-}$ pyrite (Figure 12). Arsenic typically forms $\mathrm{OH}^{-}$complexes in hydrothermal fluids $[112,113]$ and the fact that acidic fluids have less $\mathrm{OH}^{-}$than their higher $\mathrm{pH}$ counterparts leads to a lower As solubility, which may be preserved by pyrite II with characteristically lower As contents (Figure 12).

Reducing and oxidizing fluid conditions at Paleochori Bay correlate with the occurrence of high- $\mathrm{Cl}$ liquid- and low- $\mathrm{Cl}$ vapor-dominated fluids, respectively. This indicates that high- $\mathrm{Cl}$ liquid-dominated fluids were richer in $\mathrm{As}^{1-}, \mathrm{Hg}$, and $\mathrm{CO}_{2}$ leading to formation of $\mathrm{As}^{1-}$ pyrite, cinnabar, and calcite upon mixing with seawater at the seafloor. On the contrary, the low-Cl vapor-dominated fluids were more oxidizing, lower $\mathrm{pH}$, and sulfaterich, leading to formation of $\mathrm{As}^{3+}$ pyrite, barite, and alunite. This chemical distinction reflects the different reactions of vent brine-rich solutions with seawater and of vent vapor- 
rich solutions with seawater, resulting in a mineralization assemblage similar to low- and high-sulfidation epithermal systems, respectively.

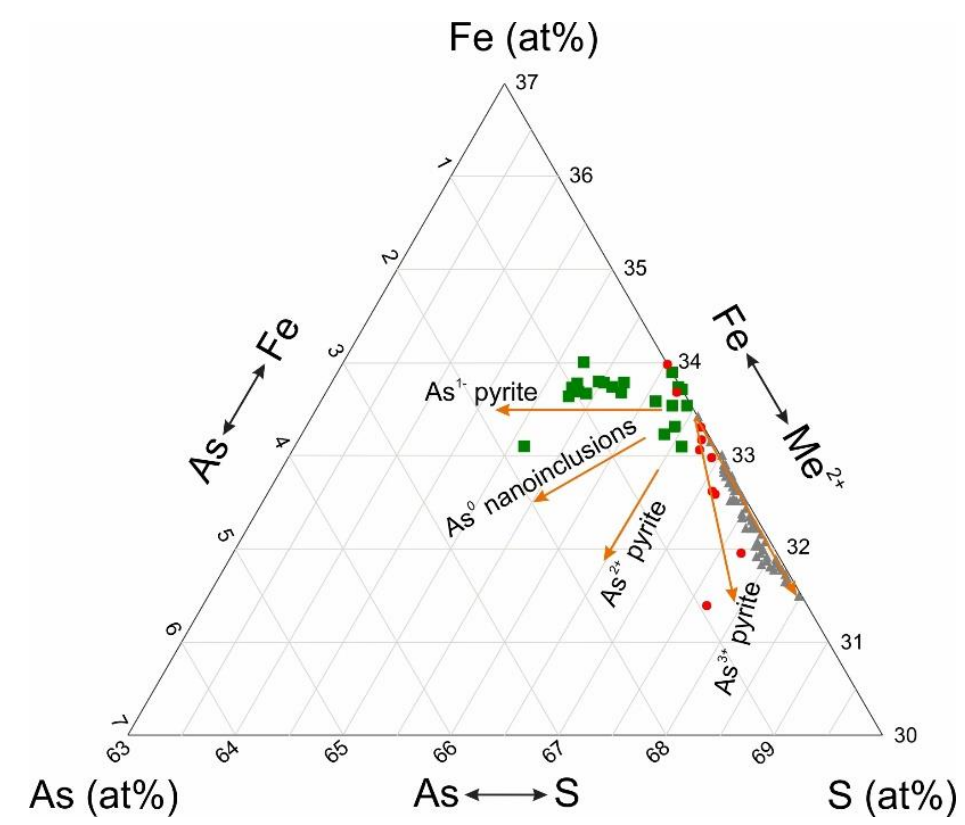

Figure 12. Ternary diagram of As-S-Fe in pyrite from Paleochori Bay (adopted from Deditius et al. [91] and Román et al. [109]). The different trends show substitution of (1) As for S (colloform As ${ }^{1-}$ pyrite I; ML38A), (2) $\mathrm{As}^{3+}$ for Fe (massive $\mathrm{As}^{3+}$ pyrite II, ML22B); and (3) substitution of divalent metals $\left(\mathrm{Me}^{2+}\right)$ for Fe (massive pyrite II, ML11A).

We propose that the sulfate-dominated fluid and its associated pyrite-alunite mineralization is caused by the reaction of $\mathrm{H}_{2} \mathrm{~S}$ originally dissolved in the deep fluid but separated upon boiling in the vapor phase with oxygenated seawater, producing $\mathrm{H}_{2} \mathrm{SO}_{4}$ rich acid-sulfate fluids in a steam-heated environment, as known from subaerial epithermal systems like those on Milos island (e.g., $[57,111,114])$. These acid fluids could leach and dissolve primary iron-rich grains from the volcaniclastic components of the sediments, and result in precipitation of pyrite and alunite. This mechanism is already proposed by Pichler et al. [30] for Lihir Island shallow submarine vents. Both alunite and jarosite often form in steam-heated environments, and jarosite may be stable relative to alunite under exceptionally low $\mathrm{pH}(\sim 1-2)$ and high $\mathrm{Fe}^{3+}$ conditions $[115,116]$. These low $\mathrm{pH}$ conditions are not documented by the fluid data from Paleochori Bay (Table 1), which is likely due to seawater mixing during the precipitation process and/or during fluid sampling. Natrojarosite surrounding alunite at Paleochori Bay therefore suggests a rapid oxidation process of $\mathrm{Fe}^{2+}$ to $\mathrm{Fe}^{3+}$ upon mixing of the vapor-rich fluids with seawater.

Alternatively, the pyrite II-alunite association at Paleochori Bay could be the result of an acidic and oxidized magmatic fluid that was contributed by the seawater-dominated hydrothermal system of Paleochori Bay, which was suggested for several arc-related submarine hydrothermal systems like Brothers volcano, Kermadec arc [21,92], Panarea, Aeolian arc [117], and high-sulfidation epithermal deposits, such as Pueblo Viejo, Dominican Republic [106], and El Indio, Chile [118].

Although a minor contribution of magmatic fluids at Paleochori Bay cannot be excluded (as evidenced from the $\delta^{11} \mathrm{~B}$ values of the vent fluids; [28]), a magmatic-hydrothermal scenario is most unlikely, because no $\mathrm{SO}_{2}$ was detected in the gas phase $[40,84]$, the $\delta^{34} \mathrm{~S}$ value of $\mathrm{H}_{2} \mathrm{~S}$ discharged to the seafloor demonstrates that any volcanic inputs were buffered by subsurface anhydrite veins [47], and finally, mineralogical evidence, such as enargite deposition is also lacking [102]. 


\subsection{Effects of Biological Activity on Sulfide Deposition}

Previous studies also suggested that biological activity may have enhanced sulfide deposition at the vent sites of Paleochori Bay $[43,46,48,50,53,83,85]$. We propose that a combination of microbial reduction of seawater sulphate (Figure 6i) together with sulfide deposition from $\mathrm{H}_{2} \mathrm{~S}$-rich fluids are responsible for the texturally diverse mineralization at Paleochori Bay (Figure 6). This indicates a biotic and abiotic $S$ cycle at Paleochori Bay, as also suggested by Houghton et al. [50] based on $\mathrm{S}$ and $\mathrm{O}$ isotope data of hydrothermal sulfides and pore water sulfates providing evidence for microbial sulfate reduction and sulfide oxidation. Furthermore, the $S$ isotope composition of pyrite in seafloor sediments records a microbially influenced signature relative to the hydrothermal endmember [50].

The formation of framboidal pyrite (Figure 6) together with orpiment-type As sulfides at Paleochori Bay has also been related to biological activity $[48,119,120]$. Framboidal pyrite formation requires a very high $\mathrm{FeS}_{2}$ supersaturation in the hydrothermal fluids resulting in nucleation rates that significantly exceed crystallization rates [121]. Such conditions can be achieved in highly oxidizing milieus [122], which occur in the discharge area where mixing between hydrothermal fluids and oxygen-rich seawater is abundant. Beyond this, sulfate reducing microbes could also account for the formation of $\mathrm{As}^{1-}$ in the fluids from which $\mathrm{As}^{1-}$ pyrite precipitates. An oxidized vapor phase, on the other hand, that condensates in seawater in a steam heated environment (cf. Section 6.2) would rather carry $\mathrm{As}^{3+}$, from which $\mathrm{As}^{3+}$ pyrite may precipitate (Figure 12). However, whether biomineralization processes at Paleochori Bay, such as biogenic reduction of seawater-derived sulfate, prevail over abiotic hydrothermal fluid related precipitation processes is a matter of further investigation.

\subsection{Comparison with Other Shallow and Very Shallow Marine Vent Sites in the Mediterranean and Elsewhere}

Active shallow (e.g., $<200 \mathrm{mbsl}$ ) seafloor (and sub-seafloor) sulfide deposition in the Mediterranean Sea occur in the Aeolian arc, Italy, and more especially at Baia di Levante, Vulcano Island, at a water depth of up to $18 \mathrm{~m}$ with temperatures $<100{ }^{\circ} \mathrm{C}$ [123], as well as on near-shore Panarea Island (8-80 mbsl) with maximum temperatures for the submarine vents up to $135^{\circ} \mathrm{C}[83,117,124-127]$ (Figure 1). At Baia di Levante, shallow water fumarolic activity results in the formation of pyrite and marcasite cementing the sand grains in the surface sediments [117]. At Panarea area, gas and thermal water venting associated with sulfide precipitation occurs at several places among others: (a) at the so-called Black Point NW of Lisca Nera (water depth of $23.5 \mathrm{~m}, \mathrm{~T}<137^{\circ} \mathrm{C}$ ), (b) in the NE of the Secca dei Panarelli (water depth of $\sim 55-85 \mathrm{~m}, \mathrm{~T}<180^{\circ} \mathrm{C}$ ), and (c) $\mathrm{N}$ of Lisca Bianca (water depth of $\left.\sim 25 \mathrm{~m}, \mathrm{~T}<150^{\circ} \mathrm{C}\right)$. Chimneys at Black Point consist of galena, pyrite, marcasite, sphalerite, and barite [126]. According to Monecke et al. [117], this site currently represents the shallowest site of polymetallic sulfide mineralization discovered in the worlds' oceans. Polymetallic sulfides NE of the Secca dei Panarelli include pyrite and marcasite, sphalerite and barite, and intergrowths of gypsum-anhydrite and of pyrite with alunite [117,124,125]. Finally, at the Lisca Bianca venting site, marcasite co-precipitates with alunite and opal [127]. Compared to the above-mentioned very shallow vent systems in the Mediterranean, the pyrite and marcasite depositional system at Paleochori Bay mineralogically strongly resembles those at Baia di Levante, Vulcano and Lisca Bianca, Panarea.

Punta Mita, Punta Banda, Bahía Concepción (Mexico) and Luise Harbor (Lihir, Papua New Guinea), in addition to Baia di Levante, Vulcano and Lisca Bianca, Panarea (see above), may also be considered as analogs to the Paleochori Bay system (Figure 1). At Punta Mita, sulfide deposition takes place from a mixture of liquid and gas that discharges on the seafloor at similar temperature $\left(\sim 85^{\circ} \mathrm{C}\right)$ and water depth $(<10 \mathrm{mbsl})$ leading to a comparable association of pyrite, cinnabar, and calcite. Similar to Paleochori Bay, the Lihir (e.g., Luise Harbor) hydrothermal field is characterized by abundant Fe sulfides deposited due to the interaction of phase-separated fluid with seawater and Fe-rich sediment at 10 to $50 \mathrm{~m}$ water depth and temperatures between $60{ }^{\circ} \mathrm{C}$ and $96^{\circ} \mathrm{C}$ [30]. The northern Baja California hydrothermal system also vents similar temperature fluids $\left(\sim 102^{\circ} \mathrm{C}\right)$ depositing 
pyrite and gypsum [36,37]. Generally, in these shallow-water hydrothermal systems, the seafloor sulfide deposition is limited because extensive sub-seafloor boiling or mixing with seawater results in sub-seafloor metal precipitation [19,35].

\subsection{Enrichment in an Epithermal Suite of Elements and Cinnabar Deposition}

The Paleochori Bay precipitates display enrichment in an epithermal suite of elements such as $\mathrm{As}, \mathrm{Hg}, \mathrm{Sb}$, and $\mathrm{Tl}$, and relatively low contents of $\mathrm{Cu}, \mathrm{Pb}$, and $\mathrm{Zn}$, varying between those reported for other very shallow systems depositing iron sulfides (pyrite and marcasite) on the seafloor, such as Punta Mita, Punta Banda, Bahía Concepción, Luise Harbor, Baia di Levante, and Panarea (Lisca Bianca) (Table 5 and text above). Arsenic, $\mathrm{Hg}$, Sb, and $\mathrm{Tl}$ contents at Paleochori Bay are also comparable to those from arc volcanoes including Panarea (Black Point and Secca dei Panarelli).

Table 5. Metal Content of samples from Paleochori Bay compared to samples from known sulfide precipitates in various very shallow (and shallow) and to arc volcanic settings elsewhere (all data in ppm).

\begin{tabular}{ccccccccccc}
\hline Element & $\begin{array}{c}\text { Milos } \\
\text { (This } \\
\text { Study) }\end{array}$ & Milos * & $\begin{array}{c}\text { Punta } \\
\text { Mita }\end{array}$ & $\begin{array}{c}\text { Punta } \\
\text { Banda }\end{array}$ & $\begin{array}{c}\text { Bahía } \\
\text { Con- } \\
\text { cepción }\end{array}$ & $\begin{array}{c}\text { Luise } \\
\text { Harbor } \\
\text { Lihir }\end{array}$ & $\begin{array}{c}\text { Panarea } \\
\text { Black } \\
\text { Point }\end{array}$ & $\begin{array}{c}\text { Panarea } \\
\text { Secca dei } \\
\text { Panarelli }\end{array}$ & $\begin{array}{c}\text { Panarea } \\
\text { Lisca } \\
\text { Bianka }\end{array}$ & $\begin{array}{c}\text { Arc Vol- } \\
\text { canoes }\end{array}$ \\
\hline $\mathrm{Nr}$ & 5 & - & 6 & 3 & 4 & 4 & 3 & 10 & 3 & 56 \\
$\mathrm{Cu}$ & 15.9 & - & 31.8 & 7.3 & 97.5 & 124 & 7 & 65 & 21 & 60,000 \\
$\mathrm{~Pb}$ & 11.1 & - & $<5$ & 8.3 & 15 & 10.8 & 110,267 & 14,162 & 20 & 13,000 \\
$\mathrm{Zn}$ & 42.8 & 53.1 & 44.3 & 107 & 76 & 255 & 327,233 & 31,067 & 100 & 105,000 \\
$\mathrm{Ag}$ & 0.1 & - & $<5$ & - & - & 0.32 & 2 & - & - & 210 \\
$\mathrm{Mn}$ & 695 & 3000 & - & 1233 & - & - & 6933 & - & 32 & - \\
$\mathrm{As}$ & 789 & 1400 & 36.8 & 5666 & 2443 & 2650 & 5700 & 317 & 69 & 1263 \\
$\mathrm{Au}$ & 0.01 & 0.01 & - & - & - & 0.05 & $<4$ & - & 9.7 \\
$\mathrm{Cd}$ & 0.1 & - & - & - & - & - & 723 & 81 & 1 \\
$\mathrm{Sb}$ & 60.0 & - & 13.0 & 767 & 75 & 86 & 83 & 143 & - & 1304 \\
$\mathrm{Tl}$ & 214 & - & 54.6 & 417 & - & 2.8 & 177 & - & 4 \\
$\mathrm{Hg}$ & 8.0 & - & 40.2 & 5333 & - & 315 & - & - & - \\
\hline
\end{tabular}

Sources: Milos * [128]; Punta Mita [32]; Punta Banda [36]; Bahía Concepción [34]; Luise Harbor, Lihir island [30]; Panarea, black point [126];

Panarea, NE of Secca dei Panarelli [125]; Panarea, Lisca Bianka [127]; average arc volcanoes [19,129]. (-): not available.

However, precipitates from arc volcanoes are much more enriched in $\mathrm{Cu}, \mathrm{Pb}$, and $\mathrm{Zn}$ compared to Paleochori due to their emplacement at greater depths and/or at higher temperatures $[19,129]$.

Active cinnabar formation is a rare feature of submarine hydrothermal systems, and was only observed at a few other localities like Punta Mita, central Mexico [32], at Punta Banda and Bahía Concepción of northern Baja California, Mexico [34-36], and Bay of Plenty (Calypso), New Zealand [38,130]. Vent precipitates with anomalously high concentrations of $\mathrm{Hg}$ have been also reported in the Lihir hydrothermal system in Papua New Guinea [30], but without any report on cinnabar deposition (Table 5). However, although the Punta Mita, the Lihir field, and the northern Baja California systems discharge fluids at about 10-50 m water depth similar to Paleochori Bay, the vents at Bay of Plenty $\left(\sim 200 \mathrm{mbsl}\right.$ ) are deeper and higher in temperature (up to $\left.200{ }^{\circ} \mathrm{C}\right)[38,130]$ compared to Paleochori Bay.

\subsection{Comparison with Other On-Shore Milos Mineralization and Sources of As and $\mathrm{Hg}$ in the Fluids}

The Paleochori precipitates contain the first documented occurrence of actively formed cinnabar on the sea floor in the Aegean and the Mediterranean area and provide an important link between offshore hydrothermal activity and the mercury- (and As-) depositing mineralizing system on western Milos Island. Mercury and arsenic are enriched (up to 24 and 4350 ppm, respectively) in the northwestern part of Milos Island, where shallow submarine epithermal mineralization at Triades-Galana, Profitis Ilias, AgathiaKondaros, 
and Katsimouti-Vani is hosted by volcanic rocks [55,58,60] (Figure 2b). Paleochori Bay also shares similarities with As- and $\mathrm{Hg}$-enriched subaqueous cherty silica present offshore at Kondaros-Agathia area where barite and natroalunite are intergrown with iron sulfides [58] (Figure 2b).

The origin of As and $\mathrm{Hg}$ in the Milos mineralization can only be speculated: Wind et al. [131] proposed that enrichments in As, $\mathrm{Tl}$, and $\mathrm{Hg}$, which were observed in deposits that occur in the hanging wall of major detachment faults (e.g., Milos), may be related to leaching from associated supra-detachment sediments of the Miocene conglomeratic sequence. However, according to Katsouri et al. [128], the volcanic arc crust is probably the source of As for the Paleochori Bay hydrothermal system, and Price et al. [46] suggested that the extremely high As contents of the Paleochori Bay fluids are due to leaching of the As-rich metamorphic basement. By expanding to the above-mentioned sources, we suggest here that underlying sulfide mineralization at Paleochori Bay, similar to those present at western Milos island, may represent a potential source for $\mathrm{As}$ and $\mathrm{Hg}$ in the Paleochori fluids and therefore its precipitates.

\section{Conclusions}

(1) We herein report the discovery of active cinnabar-depositing hydrothermal vents in a submarine setting at Paleochori Bay, within the offshore southeastern extension of the Milos Island Geothermal Field, South Aegean Active Volcanic Arc. Active, shallow-water $\left(2-10 \mathrm{~m}\right.$ ) and low temperature (up to $115^{\circ} \mathrm{C}$ ) hydrothermal venting at Paleochori Bay discharges $\mathrm{CO}_{2}$ and $\mathrm{H}_{2} \mathrm{~S}$ gas and liquid $(\mathrm{pH} \sim 3.5-7.6)$ and has led to an assemblage of sulfide and alteration mineral phases in an area of approximately $1 \mathrm{~km}^{2}$. Hydrothermal edifices recovered from the seafloor are composed of volcaniclastic detrital material cemented by pyrite and marcasite in variable proportions.

(2) Paragenetic relations indicate deposition of two distinct mineral assemblages: (1) colloform $\mathrm{As}^{1-}$ and $\mathrm{Hg}$-bearing pyrite/marcasite (Py I) together with Mn-bearing calcite and apatite, and (2) massive $\mathrm{As}^{3+}$-rich pyrite (Py II) associated with alunite/natroalunitejarosite/natojarosite solid solution and barite. Amorphous silica occur throughout the paragenetic sequence. Mercury, in the form of cinnabar, occurs in up to $3 \mu \mathrm{m}$ grains within arsenian pyrite (Py I) layers, usually forming distinct cinnabar-enriched micro-layers.

(3) A negative correlation between As and S in pyrite I suggests that $\mathrm{As}^{1-}$ substitutes for sulfur, a feature consistent with reducing, higher $\mathrm{pH}$, and low-sulfidation conditions prevailing during colloform pyrite/marcasite (Py I) and cinnabar deposition associated with calcite and apatite. Overgrowths of arsenian pyrite layers (up to $3.2 \mathrm{wt} \%$ As) onto As-free pyrite within the colloform pyrite/marcasite bands indicate fluctuation in the As content of the hydrothermal fluid. The deposition of $\mathrm{As}^{3+}$ pyrite in association with alunite is consistent with low $\mathrm{pH}$, low $\mathrm{Cl}$, vapor-dominated, and higher $\mathrm{fO}_{2}$ fluids as reflected by the positive correlation between $\mathrm{As}$ and $\mathrm{Fe}$, where As substitutes for Fe in the octahedral site of pyrite.

(4) The pyrite-bearing hydrothermal precipitates at Paleochori Bay are enriched in epithermal-type elements like $\mathrm{As}, \mathrm{Sb}, \mathrm{Tl}$ and $\mathrm{Hg}$. In addition to boiling, mixing with seawater at the seafloor and biological activity are responsible mechanisms for this epithermal-like mineralization.

(5) The Paleochori vents contain the first documented occurrence of cinnabar on the seafloor of the Aegean Sea and the Mediterranean area and provide an important link between offshore hydrothermal activity and the onshore mercury and arsenic mineralizing system on Milos Island. This study demonstrates that metal and metalloid precipitation in shallow-water continental arc environments is controlled by epithermal processes known from their subaerial analogues.

Supplementary Materials: The following are available online at https:/ / www.mdpi.com/2075-163 X/11/1/14/s1. Table S1: Electron microprobe data of pyrite from Paleochori Bay; Table S2: Electron microprobe data of calcite and barite from Paleochori Bay. 
Author Contributions: E.V.-J. and A.M. collected the studied samples. P.V. assisted by M.K. (Marianna Kati), A.M., E.V.-J., M.K. (Manuel Keith), K.H., R.K., and M.N. obtained and evaluated the mineralogical data. P.V., M.K. (Marianna Kati), A.M., and M.K. (Manuel Keith) wrote the manuscript. All authors have read and agreed to the published version of the manuscript.

Funding: Eva Valsami-Jones acknowledges fieldwork support from the National Geographic Society (NGS grant 7049-01).

Institutional Review Board Statement: Not applicable.

Informed Consent Statement: Not applicable.

Data Availability Statement: The data presented in this study are available in minerals-1046095.pdf and the Supplementary Tables S1 and S2.

Acknowledgments: Authors gratefully acknowledge financial support of the Natural History Museum of London, the British Council of Athens, and the (S.A.R.G.) of the National and Kapodistrian University of Athens. Arthur Deditius is especially thanked for his constructive comments on an earlier version of this manuscript. Two anonymous reviewers and the Editors Paolo Nimis and Theodore Bornhorst are especially thanked for their constructive comments that greatly improved the manuscript.

Conflicts of Interest: The authors declare no conflict of interest.

\section{References}

1. Hekinian, R.; Fevrier, M.; Bischoff, P.; Picot, W.; Shanks, W.C. Sulfide deposits from the East Pacific Rise near $21^{\circ}$ N. Science 1980, 207, 1433-1444. [CrossRef] [PubMed]

2. Von Damm, K.L. Seafloor hydrothermal activity: Black smoker chemistry and chimneys. Ann. Rev. Earth Planet. Sci. 1990, 18, 173-204. [CrossRef]

3. Herzig, P.M.; Hannington, M.D. Polymetallic massive sulfides at the modern seafloor, a review. Ore Geol. Rev. 1995, 10, 95-115. [CrossRef]

4. Scott, S.D. Submarine hydrothermal systems and deposits. In Geochemistry of Hydrothermal Ore Deposits; Barnes, H.L., Ed.; Wiley: New York, NY, USA, 1997; pp. 797-935.

5. Hannington, M.D.; de Ronde, C.E.J.; Petersen, S. Modern sea-floor tectonics and submarine hydrothermal systems. Econ. Geol. 2005, 100, 111-141.

6. Hannington, M.D.; Jamieson, J.; Monecke, T.; Petersen, S.; Beaulieu, S. The abundance of seafloor massive sulfide deposits. Geology 2011, 39, 1155-1158. [CrossRef]

7. German, C.R.; Petersen, S.; Hannington, M.D. Hydrothermal exploration of mid-ocean ridges: Where might the largest sulfide deposits be forming? Chem. Geol. 2016, 420, 114-126. [CrossRef]

8. Keith, M.; Haase, K.M.; Schwarz-Schampera, U.; Klemd, R.; Petersen, S.; Bach, W. Effects of temperature, sulfur and oxygen fugacity on the composition of sphalerite from submarine hydrothermal vents. Geology 2014, 48, 699-702. [CrossRef]

9. Keith, M.; Häckel, F.; Haase, K.M.; Schwarz-Schampera, U.; Klemd, R. Trace element systematics of pyrite from submarine hydrothermal vents. Ore Geol. Rev. 2016, 72, 728-745. [CrossRef]

10. Keith, M.; Haase, K.M.; Klemd, R.; Krumm, S.; Strauss, S. Systematic variations of trace element and sulfur isotope compositions in pyrite with stratigraphic depth in the Skouriotissa volcanic-hosted massive sulfide deposit, Troodos ophiolite, Cyprus. Chem. Geol. 2016, 423, 7-18. [CrossRef]

11. Humphris, S.E.; Klein, F. Progress in deciphering the controls on the geochemistry of fluids in seafloor hydrothermal systems. Ann. Rev. Mar. Sci. 2018, 10, 315-343. [CrossRef]

12. Fouquet, Y.; von Stackelberg, U.; Charlou, J.L.; Erzinger, J.; Herzig, P.M.; Muhe, R.; Wiedicke, M. Metallogenesis in back-arc environments: The Lau basin example. Econ. Geol. 1993, 88, 2154-2181. [CrossRef]

13. Herzig, P.M.; Hannington, M.D.; Arribas, A. Sulfur isotopic composition of hydrothermal precipitates from the Lau back-arc: Implications for magmatic contributions to seafloor hydrothermal systems. Miner. Depos. 1998, 33, 226-237. [CrossRef]

14. Grimaud, D.; Ishibashi, J.; Lagabrielle, Y.; Auzende, J.M.; Urabe, T. Chemistry of hydrothermal fluids from the $17^{\circ} \mathrm{S}$ active site on the North Fiji basin ridge (SW Pacific). Chem. Geol. 1991, 93, 209-218. [CrossRef]

15. Schmidt, K.; Garbe-Schönberg, D.; Hannington, M.D.; Anderson, M.O.; Bühring, B.; Haase, K.; Haruel, C.; Lupton, J.; Koschinsky, A. Boiling vapour-type fluids from the Nifonea vent field (New Hebrides Back-Arc, Vanuatu, SW Pacific): Geochemistry of an early-stage, post-eruptive hydrothermal system. Geochim. Cosmochim. Acta 2017, 207, 185-209. [CrossRef]

16. McMurtry, G.M.; Sedwick, P.N.; Fryer, P.; VonderHaar, D.L.; Yeh, H.W. Unusual geochemistry of hydrothermal vents on submarine arc volcanoes: Kasuga Seamounts, Northern Mariana Arc. Earth Planet. Sci. Lett. 1993, 114, 517-528. [CrossRef]

17. Reeves, E.P.; Seewald, J.S.; Saccocia, P.; Bach, W.; Craddock, P.R.; Shanks, W.C.; Sylva, S.P.; Walsh, E.; Pichler, T.; Rosner, M. Geochemistry of hydrothermal fluids from the PACMANUS, Northeast Pual and Vienna Woods hydrothermal fields, Manus Basin, Papua New Guinea. Geochim. Cosmochim. Acta 2011, 75, 1088-1123. [CrossRef] 
18. Halbach, P.; Pracejus, B.; Märten, A. Geology and mineralogy of massive sulfide ores from the central Okinawa trough, Japan. Econ. Geol. 1993, 88, 2210-2225. [CrossRef]

19. Monecke, T.; Petersen, S.; Hannington, M.D. Constraints on water depth of massive sulfide formation: Evidence from modern seafloor hydrothermal systems in arc-related settings. Econ. Geol. 2014, 109, 2079-2101. [CrossRef]

20. Stoffers, P.; Worthington, T.J.; Schwarz-Schampera, U.; Hannington, M.D.; Massoth, G.J.; Hekinian, R.; Schmidt, M.; Lundsten, L.J.; Evans, L.J.; Vaiomo'Unga, R.; et al. Submarine volcanoes and high-temperature hydrothermal venting on the Tonga arc, southwest Pacific. Geology 2006, 34, 453-456. [CrossRef]

21. De Ronde, C.E.J.; Massoth, G.J.; Butterfield, D.A.; Christenson, B.W.; Ishibashi, J.; Ditchburn, R.G.; Hannington, M.D.; Brathwaite, R.L.; Lupton, J.E.; Kamenetsky, V.S.; et al. Submarine hydrothermal activity and gold-rich mineralization at Brothers Volcano, Kermadec Arc, New Zealand. Miner. Depos. 2011, 46, 541-584. [CrossRef]

22. Keith, M.; Haase, K.M.; Klemd, R.; Smith, D.J.; Schwarz-Schampera, U.; Bach, W. Constraints on the source of Cu in a submarine magmatic hydrothermal system, Brothers volcano, Kermadec island arc. Contrib. Mineral. Petrol. 2018, 173, 1-16. [CrossRef]

23. Kleint, C.; Bach, W.; Diehl, A.; Fröhberg, N.; Garbe-Schönberg, D.; Hartmann, J.F.; de Ronde, C.E.J.; Sander, S.G.; Strauss, H.; Stucker, V.K.; et al. Geochemical characterization of highly diverse hydrothermal fluids from volcanic vent systems of the Kermadec intraoceanic arc. Chem. Geol. 2019, 528, 119-289. [CrossRef]

24. Kilias, S.P.; Nomikou, P.; Papanikolaou, D.; Polymenakou, P.N.; Godelitsas, A.; Argyraki, A.; Carey, S.; Gamaletsos, P.; Mertzimekis, T.J.; Stathopoulou, E.; et al. New insights into hydrothermal vent processes in the unique shallow-submarine arc-volcano, Kolumbo (Santorini), Greece. Sci. Rep. 2013, 3, 1-13. [CrossRef] [PubMed]

25. Prol-Ledesma, R.M.; Dando, P.R.; de Ronde, C.E.J. Preface Special Issue on "Shallow-water Hydrothermal Venting". Chem. Geol. 2005, 224, 1-4. [CrossRef]

26. Tarasov, V.G.; Gebruk, A.V.; Mironov, A.N.; Moskalev, L.I. Deep-sea and shallow-water hydrothermal vent communities: Two different phenomena? Chem. Geol. 2005, 224, 5-39. [CrossRef]

27. Kleint, C.; Kuzmanovski, S.; Powell, Z.; Bühring, S.I.; Sander, S.G.; Koschinsky, A. Organic Cu-complexation at the shallow marine hydrothermal vent fields off the coast of Milos (Greece), Dominica (Lesser Antilles) and the Bay of Plenty (New Zealand). Mar. Chem. 2015, 173, 244-252. [CrossRef]

28. Wu, S.F.; You, C.F.; Lin, Y.P.; Valsami-Jones, E.; Baltatzis, E. New boron isotopic evidence for sedimentary and magmatic fluid influence in the shallow hydrothermal vent system of Milos Island (Aegean Sea, Greece). J. Volcanol. Geotherm. Res. 2016, 310, 58-71. [CrossRef]

29. Pichler, T.; Dix, G.R. Hydrothermal venting within a coral reef ecosystem. Ambitle Island, Papua New Guinea. Geology 1996, 24, 435-438. [CrossRef]

30. Pichler, T.; Giggenbach, W.F.; Mcinnes, B.I.A.; Buhl, D.; Duck, B. Fe sulfide formation due to seawater-gas-sediment interaction in a shallow water hydrothermal system at Lihir Island, Papua New Guinea. Econ. Geol. 1999, 94, 281-287. [CrossRef]

31. Pichler, T.; Veizer, J.; Hall, G.E.M. The origin and chemical composition of shallow-water hydrothermal fluids in Tutum Bay, Ambitle Island, Papua New Guinea and their effect on ambient seawater. Mar. Chem. 1999, 64, 229-252. [CrossRef]

32. Prol-Ledesma, R.M.; Canet, C.; Melgarejo, J.C.; Tolson, G.; Rubio-Ramos, M.A.; Cruz-Ocampo, J.C.; Ortega-Osorio, A.; Torres-Vera, M.A.; Reyes, A. Cinnabar deposition in submarine coastal hydrothermal vents, Pacific Margin of central Mexico. Econ. Geol. 2002, 97, 1331-1340. [CrossRef]

33. Canet, C.; Prol-Ledesma, R.M.; Torres-Alvarado, I.; Gilg, H.A.; Villanueva, R.E.; Cruz, R.L.S. Silica-carbonate stromatolites related to coastal hydrothermal venting in Bahia Concepcion, Baja California Sur, Mexico. Sediment. Geol. 2005, 174, 97-113. [CrossRef]

34. Canet, C.; Prol-Ledesma, R.M.; Proenza, J.A.; Rubio-Ramos, M.A.; Forrest, M.J.; Torres Vera, M.A.; Rodriguez-Diaz, A.A. Mn-Ba$\mathrm{Hg}$ mineralization at shallow submarine hydrothermal vents in Bahia Concepcion, Baja California Sur, Mexico. Chem. Geol. 2005, 224, 96-112. [CrossRef]

35. Canet, C.; Prol-Ledesma, R.M. Mineralizing processes at shallow submarine hydrothermal vents: Examples from Mexico. Geol. Soc. Am. Spec. Pap. 2007, 422, 359-376.

36. Vidal, V.M.V.; Vidal, F.V.; Isaacs, J.D. Coastal submarine hydrothermal activity off northern Baja California. J. Geoph. Res. 1978, 83, 1757-1774. [CrossRef]

37. Vidal, V.M.V.; Vidal, F.V.; Isaacs, J.D. Coastal submarine hydrothermal activity off northern Baja California 2. Evolutionary history and isotope chemistry. J. Geoph. Res. 1981, 86, 9451-9468. [CrossRef]

38. Stoffers, P.; Hannington, M.; Wright, I.; Herzig, P.; de Ronde, C. Elemental mercury at submarine hydrothermal vents in the Bay of Plenty, Taupo volcanic zone, New Zealand. Geology 1999, 27, 931-934. [CrossRef]

39. Wohlgemuth-Ueberwasser, C.C.; Viljoen, F.; Petersen, S.; Vorster, C. Distribution and solubility limits of trace elements in hydrothermal black smoker sulfides: An in-situ LAICP-MS study. Geochim. Cosmochim. Acta 2015, 159, 16-41. [CrossRef]

40. Dando, P.R.; Hughes, J.A.; Leahy, Y.; Niven, S.J.; Taylor, L.J.; Smith, C. Gas venting rates from submarine hydrothermal areas around the island of Milos, Hellenic Volcanic Arc. Cont. Shelf Res. 1995, 15, 913-929. [CrossRef]

41. Valsami-Jones, E.; Baltatzis, E.; Bailey, E.H.; Boyce, A.J.; Alexander, J.L.; Magganas, A.; Anderson, L.; Waldron, S.; Ragnarsdottir, K.V. The geochemistry of fluids from an active shallow submarine hydrothermal system: Milos island, Hellenic Volcanic Arc. J. Volcanol. Geotherm. Res. 2005, 148, 130-151. [CrossRef]

42. Jamieson, J.W.; Hannington, M.D.; Petersen, S. Seafloor Massive Sulfide Resources. In Encyclopedia of Maritime and Offshore Engineering; John Wiley \& Sons, Ltd.: Hoboken, NJ, USA, 2017; pp. 1-10. [CrossRef] 
43. Varnavas, S.P.; Cronan, D.S. Submarine hydrothermal activity off Santorini and Milos in the Central Hellenic Volcanic Arc: A synthesis. Chem. Geol. 2005, 224, 40-54. [CrossRef]

44. Wu, S.F.; You, C.F.; Wang, B.S.; Valsami-Jones, E.; Baltatzis, E. Two-cells phase separation in shallow submarine hydrothermal system at Milos Island, Greece: Boron isotopic evidence. Geophis. Res. Lett. 2011, 38. [CrossRef]

45. Wu, S.F.; You, C.F.; Valsami-Jones, E.; Baltatzis, E.; Shen, M.L. Br/Cl and I/Cl systematics in the shallow-water hydrothermal system at Milos Island, Hellenic Arc. Mar. Chem. 2012, 140, 33-43. [CrossRef]

46. Price, R.E.; Savov, I.; Planer-Friedrich, B.; Bühring, S.; Amend, J.P.; Pichler, T. Processes influencing extreme as enrichment in shallow-sea hydrothermal fluids of Milos Island, Greece. Chem. Geol. 2013, 348, 15-26. [CrossRef]

47. Gilhooly, W.P.; Fike, D.A.; Druschel, G.K.; Kafantaris, F.C.A.; Price, R.E.; Amend, J.P. Sulfur and oxygen isotope insights into sulfur cycling in shallow-sea hydrothermal vents, Milos, Greece. Geochem. Trans. 2014, 14, 1-19. [CrossRef]

48. Godelitsas, A.; Price, R.E.; Pichler, T.; Amend, J.; Gamaletsos, P.; Göttlicher, J. Amorphous As-sulfide precipitates from the shallow-water hydrothermal vents off Milos Island (Greece). Mar. Chem. 2015, 177, 687-696. [CrossRef]

49. Duràn-Toro, V.M.; Price, R.E.; Maas, M.; Brombach, C.C.; Pichler, T.; Rezwan, K. Amorphous arsenic sulfide nanoparticles in a shallow water hydrothermal system. Mar. Chem. 2019, 211, 25-36. [CrossRef]

50. Houghton, J.L.; Gilhooly, W.P.; Kafantaris, F.C.A.; Druschel, G.K.; Lu, G.S.; Amend, J.P.; Godelitsas, A.; Fike, D.A. Spatially and temporally variable sulfur cycling in shallow-sea hydrothermal vents, Milos, Greece. Mar. Chem. 2019, 208, 83-94. [CrossRef]

51. Drummond, S.E.; Ohmoto, H. Chemical evolution and mineral deposition in boiling hydrothermal systems. Econ. Geol. 1985, 80, 126-147. [CrossRef]

52. Tarasov, V.G.; Propp, M.V.; Propp, L.N.; Zhirmunsky, A.V.; Namsaraev, B.B.; Gorlenko, V.M.; Starynin, D.A. Shallow-water gasohydrothermal vents of Ushishir Volcano and the ecosystem of Krater-naya Bight (The Kurile Islands). Mar. Ecol. 1990, 11, 1-23. [CrossRef]

53. Fitzsimons, M.F.; Dando, P.R.; Hughes, J.A.; Thiermann, F.; Akoumianaki, I.; Pratt, S.M. Submarine hydrothermal brine seeps off Milos, Greece: Observations and geochemistry. Mar. Chem. 1997, 57, 325-340. [CrossRef]

54. Christidis, G.E. Origin of the Bentonite Deposits of Eastern Milos, Aegean, Greece: Geological, Mineralogical and Geochemical Evidence. Clays Clay Miner. 1995, 43, 63-77. [CrossRef]

55. Hein, J.R.; Stamatakis, M.G.; Dowling, J.S. Trace metal-rich Quaternary hydrothermal manganese oxide and barite deposit, Milos Island, Greece. Trans. Inst. Min. Metall. 2000, 109, 67-76. [CrossRef]

56. Kilias, S.P.; Naden, J.; Cheliotis, I.; Shepherd, T.J.; Constandinidou, H.; Crossing, J.; Simos, I. Epithermal gold mineralisation in the active Aegean volcanic arc: The Profitis Ilias deposit, Milos Island, Greece. Miner. Depos. 2001, 36, 32-44. [CrossRef]

57. Naden, J.; Kilias, S.P.; Darbyshire, D.B.F. Active geothermal systems with entrained seawater as analogues for transitional continental magmato-hydrothermal and volcanic-hosted massive sulfide mineralization-The example of Milos Island, Greece. Geology 2005, 33, 541-544. [CrossRef]

58. Alfieris, D.; Voudouris, P.; Spry, P.G. Shallow submarine epithermal Pb-Zn-Cu-Au-Ag-Te mineralization on western Milos Island, Aegean Volcanic Arc, Greece: Mineralogical, Geological and Geochemical constraints. Ore Geol. Rev. 2013, 53, 159-180. [CrossRef]

59. Papavasiliou, K.; Voudouris, P.; Kanellopoulos, C.; Glasby, G.; Alfieris, D.; Mitsis, I. New geochemical and mineralogical constraints on the genesis of the Vani hydrothermal manganese deposit at NW Milos island, Greece: Comparison with the Aspro Gialoudi deposit and implications for the formation of the Milos manganese mineralization. Ore Geol. Rev. 2017, 80, 594-611. [CrossRef]

60. Smith, D.J.; Naden, J.; Miles, A.J.; Bennett, H.; Bicknell, S.H. Mass wasting events and their impact on the formation and preservation of submarine ore deposits. Ore Geol. Rev. 2018, 97, 143-151. [CrossRef]

61. Voudouris, P.; Mavrogonatos, C.; Spry, P.G.; Baker, T.; Melfos, V.; Klemd, R.; Haase, K.; Repstock, A.; Djiba, A.; Bismayer, U.; et al. Porphyry and epithermal deposits in Greece: An overview, new discoveries, and mineralogical constraints on their genesis. Ore Geol. Rev. 2019, 107, 654-691. [CrossRef]

62. Cronan, D.S.; Varnavas, S.P. Metalliferous sediments off Milos, Hellenic Volcanic Arc. Explor. Min. Geol. 1999, 8, $289-297$.

63. Stüben, D.; Glasby, G.P. Geochemistry of shallow submarine hydrothermal fluids from Paleohori Bay, Milos, Aegean Sea. Explor. Min. Geol. 1999, 8, 273-287.

64. Baltatzis, E.; Valsami-Jones, E.; Magganas, A.; Kati, M. Tamarugite from Milos island, Greece. Neues Jahrb. Mineral.-Mon. 2001, 8, 371-377.

65. Price, R.E.; Giovannelli, D. A review of the geochemistry and microbiology of marine shallow-water hydrothermal vents. Ref. Mod. Earth Syst. Environ. Sci. 2017. [CrossRef]

66. Varnavas, S.P.; Papavasiliou, C. Submarine hydrothermal mineralization processes and insular mineralization in the Hellenic Volcanic Arc system: A review. Ore Geol. Rev. 2020, 124, 103541. [CrossRef]

67. Kati, M.; Valsami-Jones, E.; Baltatzis, E.; Magganas, A. Hydrothermal precipitates from the active submarine vents in Paleochori Bay, Milos Island, Greece. In The South Aegean Active Volcanic Arc: Present Knowledge and Futue Perspectives", Proceedings of the SAAVA 2003 International Conference, Milos Island, Greece, 17-20 September 2003; George Eliopoulos: Milos Island, Greece, $2003 ;$ p. 71.

68. Kati, M.; Voudouris, P.; Magganas, A.; Valsami-Jones, E.; Baltatzis, E.; Kanellopoulos, C.; Mavrogonatos, C. Cinnabar, arsenian pyrite and thallium-enrichment in active shallow submarine hydrothermal vents at Paleochori Bay, Milos Island, Greece. In Proceedings of the EGU General Assembly, Vienna, Austria, 12-17 April 2015. 
69. Pouchou, J.L.; Pichoir, F. Quantitative analysis of homogeneous or stratified microvolumes applying the model "PAP". In Electron Probe Quantitation; Heinrich, K.F.J., Newbury, D.E., Eds.; Plenum Press: New York, NY, USA, 1991; pp. 31-75.

70. Gautier, P.; Brun, J.P. Crustal-scale geometry and kinematics of late-orogenic extension in the central Aegean (Cyclades and Evia island). Tectonophysics 1994, 238, 399-424. [CrossRef]

71. Jolivet, L.; Brun, J.P. Cenozoic geodynamic evolution of the Aegean region. Int. J. Earth Sci. 2010, 99, 109-138. [CrossRef]

72. Royden, L.; Faccenna, C. Subduction orogeny and the Late Cenozoic evolution of the Mediterranean Arcs. Ann. Rev. Earth Planet. Sci. 2018, 46, 261-289. [CrossRef]

73. Pe-Piper, G.; Piper, D.J.W. The igneous rocks of Greece: The anatomy of an orogen. In Beiträge zur Regionalen Geologie der Erde; Gebrüder Borntraeger: Berlin, Germany, 2002; p. 573.

74. Fytikas, M.; Innocenti, F.; Kolios, N.; Manetti, P.; Mazzuoli, R.; Poli, G.; Rita, F.; Villari, L. Volcanology and petrology of volcanic products from the island of Milos and neighbouring islets. J. Volcanol. Geotherm. Res. 1986, 28, 297-317. [CrossRef]

75. Stewart, A.L.; McPhie, J. Facies architecture and Late Pliocene-Pleistocene evolution of a felsic volcanic island, Milos, Greece. Bull. Volcanol. 2006, 68, 703-726. [CrossRef]

76. Stewart, A.L.; McPhie, J. Setting of epitherrnal Au deposits in a modern volcanic island arc setting, Milos, Greece: Implications for mineral exploration. In Mineral Exploration and Sustainable Development; Eliopoulos, D., Ed.; Millpress: Rotterdam, The Nederlands, 2003; pp. 533-536.

77. Alfieris, D.; Voudouris, P. High- and intermediate sulfidation Au-Ag-Te mineralization in a shallow submarine setting, Milos island, Greece: Mineralogy and geological environment of formation. In Mineral Exploration and Research: Digging Deeper; Association for Economic Geology: Dublin, Ireland, 2007; pp. 893-896.

78. Lister, G.S.; Banga, G.; Feenstra, A. Metamorphic core complexes of Cordilleran type in the Cyclades, Aegean Sea, Greece. Geology 1984, 12, 221-225. [CrossRef]

79. Grasemann, B.; Huet, B.; Schneider, D.A.; Rice, A.H.N.; Lemonnier, N.; Tschegg, C. Miocene postorogenic extension of the Eocene synorogenic imbricated Hellenic subduction channel: New constraints from Milos (Cyclades, Greece). Bull. Geol. Soc. Am. 2018, 130, 238-262. [CrossRef]

80. Voudouris, P.; Melfos, V.; Mavrogonatos, C.; Tarantola, A.; Götze, J.; Alfieris, D.; Maneta, V.; Psimis, I. Amethyst occurrences in Tertiary volcanic rocks of Greece: Mineralogical, fluid inclusion and oxygen isotope constraints on their genesis. Minerals 2018, 8, 324. [CrossRef]

81. Valsami-Jones, E.; Baltaztis, E.; Magganas, A.; Bailey, E.H.; Alexander, J.L.; Ragnarsdottir, K.V.; Kemp, A.I. The geochemistry of hydrothermal vent waters from Milos Island, Hellenic volcanic arc. Mineral. Mag. 1998, 62, 1565-1566. [CrossRef]

82. Khimasia, A.; Rovere, A.; Pichler, T. Hydrothermal areas, microbial mats and sea grass in Paleochori Bay, Milos, Greece. J. Maps 2020, 16, 348-356. [CrossRef]

83. Dando, P.R.; Stuben, D.; Varnavas, S.P. Hydrothermalism in the Mediterranean Sea. Prog. Oceanogr. 1999, 44, 333-367. [CrossRef]

84. Dando, P.R.; Aliani, S.; Arab, H.; Bianchi, C.N.; Brehmer, M.; Cocito, S.; Fowler, S.W.; Gundersen, J.; Hooper, L.E.; Kolbl, R.; et al. Hydrothermal studies in the Aegean Sea. Phys. Chem. Earth 2000, 25, 1-8. [CrossRef]

85. Price, R.E.; Lesniewski, R.; Nitzsche, K.S.; Meyerdierks, A.; Saltikov, C.; Pichler, T.; Amend, J.P. Archaeal and bacterial diversity in an arsenic-rich shallow-sea hydrothermal system undergoing phase separation. Front. Microbiol. 2013, 4, 1-19. [CrossRef]

86. Yücel, M.; Sievert, S.M.; Vetriani, C.; Foustoukos, D.I.; Giovannelli, D.; Le Bris, N. Eco-geochemical dynamics of a shallow-water hydrothermal vent system at Milos Island, Aegean Sea (Eastern Mediterranean). Chem. Geol. 2013, 356, 11-20. [CrossRef]

87. Kotopoulou, I.; Godelitsas, A.; Göttlicher, J.; Steininger, R.; Price, R.; Fike, D.A.; Amend, J.P.; Gilhooly, W.P.; Druschel, G.K.; Mertzimekis, T.J.; et al. Sulfur mineralogy and speciation in the shallow-sea hydrothermal sediments off Milos island (Greece). In Proceedings of the Goldschmidt Conference, Prague, Czech Republic, 16-21 August 2015.

88. Fytikas, M. Updating of the geological and geothermal research on Milos island. Geothermics 1989, 18, 485-496. [CrossRef]

89. Pflumio, C.; Boulegue, J.; Liakopoulos, A.; Brique, L. Oxygen, hydrogen, strontium isotopes and metals in the present-date and past geothermal systems of Milos Island (Aegean arc). In Source, Transport and Deposition of Metals; Pagel, M., Leroy, J.L., Eds.; Balkema: Rotterdam, The Nederlands, 1991; pp. 107-112.

90. Reich, M.; Kesler, S.E.; Wang, L.M.; Ewing, R.C.; Becker, U. Solubility of gold in arsenian pyrite. Geochim. Cosmochim. Acta 2005, 69, 2781-2796. [CrossRef]

91. Deditius, A.P.; Reich, M.; Kesler, S.E.; Utsunomiya, S.; Chryssoulis, S.L.; Walshe, J.; Ewing, R.C. The coupled geochemistry of Au and as in pyrite from hydrothermal ore deposits. Geochim. Cosmochim. Acta 2014, 140, 644-670. [CrossRef]

92. Keith, M.; Smith, D.J.; Jenkin, G.R.T.; Holwell, D.A.; Dye, M.D. A review of Te and Se systematics in hydrothermal pyrite from precious metal deposits: Insights into ore-forming processes. Ore Geol. Rev. 2018, 96, 269-282. [CrossRef]

93. Hanor, J.S. Barite-celestine geochemistry and environments of formation. Rev. Mineral. Geochem. 2000, 40, 193-275. [CrossRef]

94. Scott, K.M. Solid solution in, and classification of, gossan-derived members of the alunite-jarosite family, northwest Queensland, Australia. Am. Mineral. 1987, 72, 178-187.

95. Berkenbosch, H.A.; de Ronde, C.E.J.; Gemmell, J.B.; McNeill, A.W.; Goemann, K. Mineralogy and formation of black smoker chimneys from Brothers submarine Volcano, Kermadec arc. Econ. Geol. 2012, 107, 1613-1633. [CrossRef]

96. Maslennikov, V.V.; Maslennikova, S.P.; Large, R.R.; Danyushevsky, L.V. Study of trace element zonation in vent chimneys from the Silurian Yaman-Kasy volcanic hosted massive sulphide deposit (Southern Urals, Russia) using Laser Ablation-Inductively Coupled Plasma Mass Spectrometry (LA-ICPMS). Econ. Geol. 2009, 104, 1111-1141. [CrossRef] 
97. Murowchick, J.B.; Barnes, H.L. Marcasite precipitation from hydrothermal solutions. Geochim. Cosmochim. Acta 1986, 50, 2615-2629. [CrossRef]

98. Aliani, S.; Meloni, R.; Dando, P.R. Periodicities in sediment temperature time-series at a marine shallow water hydrothermal vent in Milos Island (Aegean Volcanic arc, Eastern Mediterranean). J. Mar. Syst. 2004, 46, 109-119. [CrossRef]

99. Hannington, M.D.; Thompson, G.; Rona, P.A.; Scott, S.D. Gold and native copper in supergene sulphides from the Mid-Atlantic Ridge. Nature 1988, 333, 64-66. [CrossRef]

100. Keith, M.; Smith, D.J.; Doyle, K.; Holwell, D.A.; Jenkin, G.R.T.; Barry, T.L.; Becker, J.; Rampe, J. Pyrite chemistry: A new window into $\mathrm{Au}$-Te ore-forming processes in alkaline epithermal districts, Cripple Creek, Colorado. Geochim. Cosmochim. Acta 2020, $274,172-191$. [CrossRef]

101. Cook, N.J.; Chryssoulis, S.L. Concentrations of "invisible gold" in the common sulfides. Can. Mineral. 1990, $28,1-16$.

102. Einaudi, M.T.; Hedenquist, J.W.; Inan, E.E. Sulfidation state of fluids in active and extinct hydrothermal systems: Transitions from porphyry to epithermal environments. Soc. Econ. Geol. Spec. Publ. 2003, 10, 285-313.

103. Deditius, A.P.; Utsunorniya, S.; Renock, D.; Ewing, R.C.; Ramana, C.V.; Becker, U.; Kesler, S.E. A proposed new type of arsenian pyrite: Composition, nanostructure and geological significance. Geochim. Cosmochim. Acta 2008, 72, 2919-2933. [CrossRef]

104. Deditius, A.P.; Utsunomiya, S.; Ewing, R.C.; Chryssoulis, S.L.; Venter, D.; Kesler, S.E. Decoupled geochemical behavior of As and $\mathrm{Cu}$ in hydrothermal systems. Geology 2009, 37, 707-710. [CrossRef]

105. Deditius, A.P.; Utsunomiya, S.; Ewing, R.C.; Kesler, S.E. Nanoscale “liquid" inclusions of As-Fe-S in arsenian pyrite. Am. Miner. 2009, 94, 391-394. [CrossRef]

106. Deditius, A.P.; Utsunomiya, S.; Reich, M.; Kesler, S.E.; Ewing, R.C.; Hough, R.; Walshe, J. Trace metal nanoparticles in pyrite. Ore Geol. Rev. 2011, 42, 32-46. [CrossRef]

107. Kesler, S.E.; Deditius, A.; Ewing, R.; Utsunomiya, S. Arsenian Pyrite in Epithermal and Carlin-type Deposits: Implications for Processes and Sources. In Proceedings of the Geological Society of Nevada, Reno, NV, USA, 14-22 May 2010.

108. Qian, G.; Brugger, J.; Testamale, D.; Skiner, W.; Pring, A. Formation of As(II)-pyrite during experimental replacement of magnetite under hydrothermal conditions. Geochim. Cosmochim. Acta 2013, 100, 1-10. [CrossRef]

109. Román, N.; Reich, M.; Leisen, M.; Morata, D.; Barra, F.; Deditius, A.P. Geochemical and micro-textural fingerprints of boiling in pyrite. Geochim. Cosmochim. Acta 2019, 264, 60-85. [CrossRef]

110. Simon, G.; Huang, H.; Penner-Hahn, J.E.; Kesler, S.E.; Kao, L.S. Oxidation state of gold and arsenic in gold-bearing arsenian pyrite. Am. Mineral. 1999, 84, 1071-1079. [CrossRef]

111. Hedenquist, J.W.; Arribas, A.R.; Gonzalez-Urien, E. Exploration for epithermal gold deposits. Rev. Econ. Geol. 2000, 13, 245-277.

112. Pokrovski, G.S.; Zakirov, I.V.; Roux, J.; Testemale, D.; Hazemann, J.-L.; Bychkov, A.Y.; Golikova, G.V. Experimental study of arsenic speciation in vapor phase to $500{ }^{\circ} \mathrm{C}$ : Implications for as transport and fractionation in low-density crustal fluids and volcanic gases. Geochim. Cosmochim. Acta 2002, 66, 3453-3480. [CrossRef]

113. Pokrovski, G.S.; Borisova, A.Y.; Bychkov, A.Y. Speciation and transport of metals and metalloids in geological vapors. Rev. Mineral. Geochem. 2013, 76, 165-218. [CrossRef]

114. Sillitoe, R.H. Epithermal paleosufaces. Mineral. Depos. 2015, 50, 767-793. [CrossRef]

115. Stoffregen, R. Stability relations of jarosite and natrojarosite at 100-250 ${ }^{\circ}$ C. Geochim. Cosmochim. Acta 1993, 57, $2417-2429$. [CrossRef]

116. Rye, R.O.; Alpers, C.N. The Stable Isotope Geochemistry of Jarosite; US Geological Survey Open-File Report: Reston, VA, USA, 1997; pp. 88-97.

117. Monecke, T.; Petersen, S.; Augustin, N.; Hannington, M.D. Seafloor hydrothermal systems and associated mineral deposits of the Tyrrhenian Sea. Mem. Descr. Carta Geol. d'It. 2019, 104, 41-74.

118. Tanner, D.; Henley, R.W.; Mavrogenes, J.A.; Holden, P. Sulfur isotope and trace element systematics of zoned pyrite crystals from the El Indio Au-Cu-Ag deposit, Chile. Contrib. Mineral. Petrol. 2016, 171, 1-17. [CrossRef]

119. Alfonso, P.; Prol-Ledesma, R.M.; Canet, C.; Melgarejo, J.C.; Fallick, A.E. Isotopic evidence for biogenic precipitation as a principal mineralization process in coastal gasohydrothermal vents, Punta Mita, Mexico. Chem. Geol. 2005, 224, 113-121. [CrossRef]

120. Dekov, V.M.; Bindi, L.; Burgaud, G.; Petersen, S.; Asael, D.; Rédou, V.; Fouquet, Y.; Pracejus, B. Inorganic and biogenic As-sulfide precipitation at seafloor hydrothermal fields. Mar. Geol. 2013, 342, 28-38. [CrossRef]

121. Prol-Ledesma, R.M.; Canet, C.; Villanueva-Estrade, R.E.; Ortega-Osorio, A. Morphology of pyrite in particulate matter from shallow submarine hydrothermal vents. Am. Mineral. 2010, 95, 1500-1507. [CrossRef]

122. Ohfuji, H.; Rickard, D. Experimental syntheses of framboids-A review. Earth Sci. Rev. 2005, 71, 147-170. [CrossRef]

123. Wauschkuhn, A.; Gröpper, H. Rezente Sulfidbildung auf und bei Vulcano, Äolische Inseln, Italien. N. Jb. Min. Abh. 1975, $126,87-111$.

124. Marani, M.P.; Gamberi, F.; Savelli, C. Shallow-water polymetallic sulfide deposits in the Aeolian island arc. Geology 1997, 25, 815-818. [CrossRef]

125. Savelli, C.; Marani, M.; Gamberi, F. Geochemistry of metalliferous, hydrothermal deposits in the Aeolian arc (Tyrrhenian Sea). J. Volanol. Geotherm. Res. 1999, 88, 305-323. [CrossRef]

126. Becke, R.; Merkel, B.; Pohl, T. Mineralogical and geological characteristics of the shallow-water massive sulfide precipitates of Panarea, Aeolian Islands, Italy. In Research in Shallow Marine and Fresh Water Systems; Freiberg Online Geology; Merkely, B., Schipek, M., Eds.; TU Bergakademie Freiberg: Freiberg, Germany, 2009; pp. 94-100. 
127. Dekov, V.M.; Kamenov, G.D.; Abrasheva, M.D.; Capaccioni, B.; Munnik, F. Mineralogical and geochemical investigation of seafloor massive sulfides from Panarea Platform (Aeolian Arc, Tyrrhenian Sea). Chem. Geol. 2013, 335, 136-148. [CrossRef]

128. Katsouri, S.; Scott, S.D.; Gorton, M.P.; Magganas, A.; Valsami-Jones, E.; Baltatzis, E.; Kati, M. Formation of hydrothermal sulfides in active shallow water systems: The role of freshwater vs seawater. In SEG 2004: Predictive Mineral Discovery Under Cover, Proceedings of the SEG Eugen Stumpfl Memorial Symposium, Perth, Australia, 27 September-1 October 2004; Muhling, J., Ed.; The University of Western Australia, Centre for Global Metallogeny: Perth, Australia, 2004; pp. 220-223.

129. Monecke, T.; Petersen, S.; Hannington, M.D.; Grant, H.; Samson, I.M. The Minor Element Endowment of Modern Sea-Floor Massive Sulfides and Comparison with Deposits Hosted in Ancient Volcanic Successions. Rev. Econ. Geol. 2016, 18, 245-306.

130. Nestmeyer, M. Mineralogy and Geochemistry of Hydrothermal Mineralisations Calypso Vents and Paleochori Bay. Master's Thesis, Friedrich-Alexander-Universität Erlangen-Nürnberg, GeoZentrum Nordbayern, Erlangen, Germany, November 2019.

131. Wind, S.C.; Schneider, D.A.; Hannington, M.D.; McFarlane, C.R.M. Regional similarities in lead isotopes and trace elements in galena of the Cyclades Mineral District, Greece with implications for the underlying basement. Lithos 2020, 366-367, 105559. [CrossRef] 